\title{
Role of Neuroactive Steroid Allopregnanolone in Antipsychotic-like Action of Olanzapine in Rodents
}

\author{
Rajesh R Ugale', Khemraj Hirani', Micaela Morelli ${ }^{2}$ and Chandrabhan T Chopde*,I \\ 'University Department of Pharmaceutical Sciences, Nagpur University Campus, Nagpur, Maharashtra, India; ${ }^{2}$ Department of Toxicology and \\ Center of Excellence for Neurobiology of Dependence, University of Cagliari, Cagliari, Italy
}

\begin{abstract}
Olanzapine increases brain allopregnanolone (ALLO) levels sufficiently to modulate neuronal activity by allosterically regulating $G_{A B A}$ receptors. Recently, we reported the antipsychotic-like profile of ALLO in rodents. The present study examined the hypothesis that olanzapine-induced elevation of endogenous neurosteroid ALLO is vital for its neuroleptic-like action. The conditioned avoidance response (CAR) and apomorphine-induced climbing behavioral paradigms were used in rodents. Administration of ALLO (I $\mu$, intracerebroventricular (i.c.v.)) or neurosteroidogenic agents such as the mitochondrial diazepam binding inhibitor receptor agonist, FGIN I-27 (0.5 $\mu$ g, i.c.v.) or the ALLO precursor, progesterone ( $10 \mathrm{mg} / \mathrm{kg}$, i.p.) significantly potentiated olanzapine-induced blockade of CAR and apomorphine-induced climbing. In contrast, these agents failed to alter the antipsychotic-like effect of risperidone and haloperidol. On the other hand, inhibition of the endogenous biosynthesis of neurosteroids by the $3 \beta$-hydroxysteroid dehydrogenase inhibitor, trilostane $\left(30 \mathrm{mg} / \mathrm{kg}\right.$, i.p.), the $3 \alpha$-hydroxysteroid oxidoreductase inhibitor, indomethacin $\left(5 \mathrm{mg} / \mathrm{kg}\right.$, i.p.), or the GABA $\mathrm{A}_{\mathrm{A}}$ receptor antagonist bicuculline (I mg/kg, i.p.) and dehydroepiandrosterone sulfate (DHEAS) (I mg/kg, i.p.) blocked the effect of olanzapine, but not of risperidone and haloperidol. Socially isolated animals, known to exhibit decreased brain ALLO and GABA $A$ receptor functions, displayed a shortening in the muscimol-induced loss of righting reflex and an increased susceptibility to apomorphine-induced climbing. Administration of olanzapine, but not of haloperidol and risperidone, normalized the duration of muscimol-elicited loss of righting reflex. Although all three antipsychotics proved capable of antagonizing the apomorphine-induced climbing, a dose almost five times higher of olanzapine was required in socially isolated animals. The data obtained suggest that enhancement of the GABAergic tone plays a key role in the antipsychotic-like effect exerted by olanzapine in rodents, likely as a consequence of augmented levels of neuroactive steroids, in particular ALLO, in the brain. The present findings provide the first specific behavioral evidence in support of the hypothesis that neuroactive steroid ALLO- mediated GABAergic modulation is essential for the antipsychotic-like action of olanzapine.

Neuropsychopharmacology (2004) 29, 1597-1609, advance online publication, 2 I April 2004; doi: I0.1038/sj.npp. I 300460
\end{abstract}

Keywords: neuroactive steroid; allopregnanolone; olanzapine; risperidone; haloperidol; $\mathrm{GABA}_{\mathrm{A}}$ receptors

\section{INTRODUCTION}

Olanzapine, a thienobenzodiazepine, is an atypical antipsychotic drug generally considered as being superior to classical antipsychotics (Robertson and Fibiger, 1996; Beasley et al, 1996; Madhusoodanan et al, 1999, 2001). Olanzapine exhibits anxiolytic activity (Moore et al, 1994) and improves memory and cognitive functions in rodents (Nowakowska et al, 1999). It displays affinity for many neuronal receptors including histamine $\mathrm{H}_{1}$, serotonin $5-\mathrm{HT}_{2 \mathrm{~A}}, 5-\mathrm{HT}_{2 \mathrm{~B}}, 5-\mathrm{HT}_{2 \mathrm{C}}, 5-\mathrm{HT}_{3}$, and $5-\mathrm{HT}_{6}$, dopamine

\footnotetext{
*Correspondence: Dr Professor CT Chopde, University Department of Pharmaceutical Sciences, Nagpur University Campus, Nagpur 440 033, Maharashtra, India, Tel: + 9 I 7I2 2500355/2500324, Fax: +91 7I2 2563456/2500355, E-mail: chopdect@edumail.nic.in Received 30 November 2003; revised 8 March 2004; accepted 15 March 2004

Online publication: 17 March 2004 at http://www.acnp.org/citations/ Npp03170403550/default.pdf
}

$\mathrm{D}_{1}-\mathrm{D}_{5}$, muscarinic, $\alpha$ and glutamate receptors (Richelson and Souder, 2000). The multiple binding property of olanzapine contributes to its varied pharmacological and therapeutic effects (Roth et al, 1994; Bymaster and Falcon, 2000; Bymaster et al, 1996, 1999, 2001). However, the precise mechanism underlying its antipsychotic action remains unclear. The potent $5-\mathrm{HT}_{2}$ receptor antagonism and weak $\mathrm{D}_{1}$ and $\mathrm{D}_{2}$ receptor antagonism have been suggested to play a key role in its atypical antipsychotic activity (Beasley et al, 1996). Furthermore, the potent antagonistic activity of olanzapine on $5-\mathrm{HT}_{3}$ and $5-\mathrm{HT}_{6}$ receptors may also contribute towards its antipsychotic effect (Bymaster et al, 2001). Emerging evidence suggests that in addition to dopaminergic and serotonergic antagonism, GABAergic neurotransmission may serve as a primary locus for some antipsychotic drugs, including olanzapine (Farnbach-Pralong et al, 1998; Carpenter et al, 1999; O'Connor, 2001). Recent studies have shown subdued GABAergic neurotransmission in schizophrenics (Akbarian 
et al, 1995; Lewis, 2000; Benes and Berretta, 2001), while antipsychotics-like clozapine and olanzapine were found to increase the GABA release in the nucleus accumbens (Drew et al, 1990; Osborne et al, 1994; O'Connor, 2001). Furthermore, the density of GABAergic interneurons decreases in corticolimbic regions coupled with a simultaneous increase in the density of postsynaptic GABA receptors in the same brain regions of schizophrenic subjects (Benes, 1995). Olanzapine exerts no direct action on the $\mathrm{GABA}_{\mathrm{A}}$ receptors as it shows very low affinity for these receptors (Bymaster et al, 1996; Schotte et al, 1996). However, chronic olanzapine administration remarkably decreases the density of $\mathrm{GABA}_{\mathrm{A}}$ receptors in rat hippocampus and temporal cortex (Farnbach-Pralong et al, 1998). Several studies have also indicated a close relationship between GABA and dopamine, involved in the precipitation of schizophrenia. Dopamine mediates the modulation of GABAergic neurotransmission in those brain regions, including nucleus accumbens and ventral tegmental area, involved in schizophrenia (Penit-Soria et al, 1987; Pennartz et al, 1992; Pirot et al, 1992; Pralong and Jones, 1993; Cameron and Williams, 1993; Law-Tho et al, 1994).

It has recently been demonstrated that both olanzapine and clozapine, but not risperidone and haloperidol, elevate brain cortical levels of the $\mathrm{GABA}_{\mathrm{A}}$-positive neuroactive steroid allopregnanolone (ALLO), leading to a putative increase in GABAergic tone (Barbaccia et al, 2001; Marx et al, 2000, 2003). Neuroactive steroids including ALLO are synthesized de novo in the brain from cholesterol or from peripheral steroids in adrenal or gonads (Purdy et al, 1991, 1992) and are present in the CNS at concentrations that may modulate $\mathrm{GABA}_{\mathrm{A}}$ receptor function (Paul and Purdy, 1992; Robel and Baulieu, 1995; Bixo et al, 1997; Rupprecht and Holsboer, 1999). ALLO increases the GABA-mediated chloride ion $\left(\mathrm{Cl}^{-}\right)$flux through $\mathrm{GABA}_{\mathrm{A}}$ receptors and is 20 -fold more potent than benzodiazepines and 200-fold more potent than barbiturates (Majewska et al, 1986; Morrow et al, 1987, 1990). High doses of ALLO increase GABAergic tone leading to suppression of dopaminergic transmission (Motzo et al, 1996; Van Kammen, 1977; Khisti et al, 1998) and elicit a behavioral profile similar to that of the $\mathrm{D}_{2}$-receptor antagonist haloperidol (Khisti et al, 2002). ALLO exerts multiple effects in CNS including anxiolysis (Wieland et al, 1991), antistress (Zimmerberg and Blaskey, 1998), antidepressant (Khisti and Chopde, 2000; Khisti et al, 2000), and anticonvulsant activity (Frye, 1995), in addition to its neuroleptic-like activity (Khisti et al, 2002). Accumulating evidence suggests that physiological fluctuations in brain concentrations of neuroactive steroids contribute towards the genesis, development and course of neurological and psychiatric or affective disorders (George et al, 1994; Bixo et al, 1997; Hill et al, 2000). For example, a variation of ALLO concentration across the menstrual cycle are probably involved in the cyclic mood changes observed with premenstrual tension syndrome (Wang et al, 1996).

The paucity of behavioral data suggesting ALLO involvement in the antipsychotic action of olanzapine persuaded us to design different approaches with altered ALLO content. We studied the influence of various agents affecting neurosteroidogenesis and determined the essentiality of increased ALLO content by olanzapine as compared to risperidone and haloperidol. Animal behavioral paradigms widely used to predict antipsychotic activity (Arnt, 1982; Moore and Axton, 1988) were applied. In addition, neuroleptic activity was evaluated in protracted social isolation. This paradigm has been widely employed to investigate the influences of decreased cortical ALLO content and $\mathrm{GABA}_{\mathrm{A}}$ receptor function (Serra et al, 2000; Dong et al, 2001; Guidotti et al, 2001). The aim of this study was to provide the specific behavioral evidences to support the hypothesis that neuroactive steroid ALLO-mediated GABAergic modulation is essential for antipsychotic-like action of olanzapine.

\section{MATERIALS AND METHODS}

\section{Subjects}

All procedures were carried out under strict compliance with ethical principles and guidelines of the Committee for the Purpose of Control and Supervision of Experimental Animals, Ministry of Environment and Forests; Government of India; New Delhi. Young healthy male, Sprague-Dawley rats (180-220 g) and Swiss albino mice (20-25 g) were used in the study. Rats or mice were group housed in separate cages (five per cage) except the mice that were employed for social isolation. Social isolates were kept individually (cage of $24 \times 17 \times 12 \mathrm{~cm}$ ) for 6 weeks before conducting the experiments. All animals were kept under standard 12:12-h light/dark cycle (lights on $0700 \mathrm{~h}$ ) in a temperature controlled $\left(24 \pm 1^{\circ} \mathrm{C}\right)$ environment with ad libitum access to rodent chow (Lipton, India) and tap water.

Experiments were performed during the light cycle between 0900 and $1400 \mathrm{~h}$ to avoid circadian variation in the brain concentrations of neuroactive steroids (Robel et al, 1987). Each experimental group had separate sets of animals and the care was taken to ensure that animals used for one response were not employed elsewhere. Further, an individual animal of a group, subjected once for an experimental effect, was not used again under any condition. Animals were habituated to laboratory conditions for 1 week prior to beginning of experimental protocols to minimize, if any, nonspecific stress induced steroid increase.

\section{Drugs and Administration}

The neuroactive steroid ALLO, the mitochondrial diazepam binding inhibitory receptor (MDR) agonist $N, N$-di- $n$-hexyl2-(4-fluorophenyl)-1H-indol-3-acetamide (FGIN 1-27), the $\mathrm{GABA}_{\mathrm{A}}$ receptor antagonist bicuculline, the $\mathrm{GABA}_{\mathrm{A}}$ receptor allosteric antagonist dehydroepiandrosterone sulfate (DHEAS), the specific $\mathrm{GABA}_{\mathrm{A}}$ receptor agonist muscimol, the ALLO precursor progesterone, and the dopamine receptors agonist apomorphine were purchased from RBI, USA. Atypical antipsychotics olanzapine and risperidone (Sun Pharmaceutical Advanced Research Center, Baroda, India), typical antipsychotic haloperidol (Searle, India), neuroactive steroid biosynthesis inhibitors trilostane (Sanofi Winthrop Development Center, UK), and Indomethacin (Zim Laboratories, India) were received as gifts.

ALLO, FGIN 1-27, olanzapine, risperidone, trilostane, indomethacin, DHEAS, and progesterone were dissolved in $(45 \% \mathrm{w} / \mathrm{v})$ solution of 2 -hydroxypropyl- $\beta$-cyclodextrin and 
diluted with $0.9 \%$ saline. For intracerebroventricular (i.c.v.) administration of drugs, dilutions were made with artificial cerebrospinal fluid (aCSF) of following composition $0.2 \mathrm{M}$ $\mathrm{NaCl}, 0.02 \mathrm{M} \mathrm{NaH}_{2} \mathrm{CO}_{3}, 2 \mathrm{mM} \mathrm{KCl}, 0.5 \mathrm{mM} \mathrm{KH}{ }_{2} \mathrm{PO}_{4}, 1.2 \mathrm{mM}$ $\mathrm{CaCl}_{2}, \quad 1.8 \mathrm{mM} \quad \mathrm{MgCl}_{2}, \quad 0.5 \mathrm{mM} \quad \mathrm{Na}_{2} \mathrm{SO}_{4}$, and $5.8 \mathrm{mM}$ D-glucose. Other drugs were dissolved or diluted in $0.9 \%$ saline.

All drugs were injected by intraperitoneal (i.p.) route with the exception of ALLO and FGIN 1-27 that were injected by i.c.v. route to circumvent their rapid metabolism in the liver and avoid peripheral effects, which could have interfered with behavioral studies, while apomorphine was injected by subcutaneous route (s.c.). At the most, two injections were given to each rat in conditioned avoidance response paradigm or to each mouse in climbing experiments before apomorphine treatment. Respective controls were maintained simultaneously by vehicle treatment at specific time intervals to study the effect of multiple injections or repeated handling stress for each experiment.

\section{Intracerebroventricular Administration}

The i.c.v. injections in rats (Sanchez-Blazquez et al, 1995; Bilsky et al, 1996; Khisti et al, 2002) and mice (Akwa et al, 2001; Hirani et al, 2002) were administered as described earlier. Rats were anaesthetized with pentobarbital sodium $(50 \mathrm{mg} / \mathrm{kg}$, i.p.) and fixed in a stereotaxic frame (Stoelting Co., IL, USA). A permanent 22-gauge stainless steel guide cannulae 313-G/Spc (Plastics One Inc., Virginia, USA) was implanted aseptically into the right lateral ventricle (coordinates from Paxinos and Watson, 1998; posterior $-0.8 \mathrm{~mm}$; lateral from midline $+1.2 \mathrm{~mm}$ and ventral $-3.5 \mathrm{~mm}$; relative to bregma). For mice i.c.v. injections, guide cannulae (28 gauge) were stereotaxically implanted with the coordinates from Paxinos and Franklin (1997) (AP $-0.22 \mathrm{~mm}$; $\mathrm{ML}+1 \mathrm{~mm}$ and $\mathrm{DV}-2.5 \mathrm{~mm}$; relative to bregma) under pentobarbital sodium $(60 \mathrm{mg} / \mathrm{kg}$, i.p.) anesthesia. The guide cannula was secured to the skull using mounting screws (Plastic One) and dental cement (Dental Products of India, Mumbai). A stainless steel dummy cannula was used to occlude the guide cannula when not in use. The animals were then allowed to recover for 1 week, during which they were habituated to the experimental protocols to minimize nonspecific stress. Injections were made using a Hamilton microliter syringe (Hamilton, Nevada, USA) connected to internal cannula (30 gauge) by polyethylene tubing and a volume of $5 \mu \mathrm{l}$ was administered over a period of $1 \mathrm{~min}$ into the right lateral ventricle. The injection cannula was left in place for further $1 \mathrm{~min}$ before being slowly withdrawn to avoid back flow. At the end of all i.c.v. experiments, dilute India ink was injected (i.c.v.) and animals were killed immediately. Only data from animals showing uniform distribution of ink into lateral ventricles were used for statistical analysis.

\section{Experiment 1: Dose-Related Effect of Antipsychotics}

Conditioned avoidance response (CAR). Rats were trained individually to move from one compartment of a shuttle box (Techno Labs, Lucknow) into other upon presentation of the 10-s buzzer tone (conditioned stimulus; CS). If the rat failed to respond, the tone was further continued with an unconditioned stimulus (UCS) in the form of an electric shock $(0.5 \mathrm{~mA})$, delivered to the grid floor of the chamber for a period of $10 \mathrm{~s}$. Each animal was subjected to a daily session of 10 trials separated by a 20 -s intertrial interval. The trial terminated once the rat has moved into the other compartment during CS or UCS period. Crossings made during the CS period were recorded as avoidance responses and those made during UCS period were recorded as escape responses. All animals were trained for a week. Only those animals characterized by a high level of avoidance responding $(>80 \%)$ were used for further experiments. Separate groups of trained rats ( $n=7$ per group) were employed for individual dose effect of antipsychotics. They were treated i.p. with olanzapine $(1-2 \mathrm{mg} / \mathrm{kg})$, risperidone $(0.3-0.5 \mathrm{mg} / \mathrm{kg})$, haloperidol $(0.1-0.3 \mathrm{mg} / \mathrm{kg})$, or vehicle $(0.2 \mathrm{ml} / \mathrm{rat}) ; 30 \mathrm{~min}$ thereafter, rats were placed individually in the shuttle box for the standard 10 trial session of CAR. The results are expressed as avoidance/10 trials.

Apomorphine-induced climbing behavior. Administration of apomorphine to mice results in a peculiar climbing behavior characterized initially by rearing and then fullclimbing activity (Costall et al, 1978). The ability of a drug to antagonize apomorphine-induced climbing behavior in the mouse has been correlated with neuroleptic activity (Costall et al, 1978). For the purpose of the climbing test, mice were initially placed individually in cylindrical wire mesh cages (height $13 \mathrm{~cm}$, diameter $14 \mathrm{~cm}$, mesh size $3 \mathrm{~mm}$ ) for $60 \mathrm{~min}$ to acclimatize to the new environment. Separate groups of mice were used for each dose of individual antipsychotics. They were injected (i.p.) with olanzapine $(0.5-2 \mathrm{mg} / \mathrm{kg})$, risperidone $(0.2-0.4 \mathrm{mg} / \mathrm{kg})$, haloperidol $(0.1-0.3 \mathrm{mg} / \mathrm{kg})$, or vehicle $(0.2 \mathrm{ml}) 30 \mathrm{~min}$ before apomorphine $(1 \mathrm{mg} / \mathrm{kg}$, s.c.) administration. Animals were subsequently placed individually in wire mesh cages $10 \mathrm{~min}$ after apomorphine administration and their climbing behavior was scored at 5-min intervals for a period of $20 \mathrm{~min}$ as follows: $0=$ four paws on the floor, $1=$ one paw on the wall of cage, $2=$ two paws on the wall of cage, $3=$ three paws on the wall of cage, $4=$ four paws on the wall of cage. Climbing scores across each time interval were then summed and expressed as climbing index, thus providing a maximum possible climbing index of 20 .

\section{Experiments 2 and 3: Influence of ALLO or Its Endogenous Increase on the Action of Antipsychotics}

Two separate experimental designs were set with different groups of animals in each of the treatment protocols.

Experiment 2. Firstly, we examined the dose-related effects of ALLO or neurosteroidogenic drugs alone on escape and avoidance behaviors in rats and apomorphine-induced climbing behavior in mice. For CAR experiments, trained rats were divided into different groups $(n=7)$ and injected aCSF ( $5 \mu \mathrm{l} / \mathrm{rat}$, i.c.v.), ALLO (1-4 $\mu \mathrm{g} / \mathrm{rat}$, i.c.v.), an ALLO precursor progesterone (10-30 $\mathrm{mg} / \mathrm{kg}$, i.p.), or MDR agonist FGIN 1-27 (0.5-1 $\mu \mathrm{g} / \mathrm{rat}$, i.c.v.) that increases endogenous ALLO content. At $15 \mathrm{~min}$ after i.c.v. or $30 \mathrm{~min}$ after i.p. injection, rats were placed individually in the shuttle box for the standard 10 trial session of CAR to record escape and avoidance behaviors. Similarly, separate groups of mice 
$(n=7)$ received identical treatment of ALLO or its enhancers as mentioned above and $15 \mathrm{~min}$ after i.c.v. or $30 \mathrm{~min}$ after i.p. administration; all mice were challenged with apomorphine $(1 \mathrm{mg} / \mathrm{kg}$, s.c.). The climbing behavior was assessed at 5-min interval for $20 \mathrm{~min}$, starting $10 \mathrm{~min}$ after apomorphine injection.

Experiment 3. Secondly, the protocols were designed to examine whether the ALLO or neurosteroidogenic agents modulate the action of antipsychotics on CAR and apomorphine-induced climbing behaviors. Animals were treated with subeffective doses of ALLO (1 $\mu$ g, i.c.v.), progesterone (10 mg/kg, i.p.), or FGIN 1-27 (0.5 $\mu$ g, i.c.v.) and $15 \mathrm{~min}$ after i.c.v. or $30 \mathrm{~min}$ after i.p. injection, they received subeffective dose of antipsychotic or vehicle $(0.2 \mathrm{ml})$. The subeffective doses of antipsychotics used in rats (olanzapine $1 \mathrm{mg} / \mathrm{kg}$, risperidone $0.3 \mathrm{mg} / \mathrm{kg}$, or haloperidol $0.1 \mathrm{mg} / \mathrm{kg}$ ) for CAR experiments and in mice (olanzapine $0.5 \mathrm{mg} / \mathrm{kg}$, risperidone $0.2 \mathrm{mg} / \mathrm{kg}$, or haloperidol $0.1 \mathrm{mg} / \mathrm{kg}$ ) for climbing test were selected on the basis of dose-related study from experiment 1 . Following $30 \mathrm{~min}$ of antipsychotics, rats were subjected to CAR test for escape and avoidance behaviors, while mice were injected apomorphine $(1 \mathrm{mg} / \mathrm{kg}$, s.c.) for climbing test as described above.

\section{Experiments 4 and 5: Influence of Neurosteroid Biosynthesis Inhibitors or Agents Capable of Reducing $\mathrm{GABA}_{\mathrm{A}}$ Receptor Activation on the Action of Antipsychotics}

In order to study the influence of low neurosteroid content or decreased GABAergic activation on antipsychotic-like effect of olanzapine, risperidone, and haloperidol, following treatment protocols were designed.

Experiment 4. The de novo neurosteroid biosynthesis inhibitors indomethacin and trilostane were used either alone or in combination with effective doses of antipsychotics (olanzapine $2 \mathrm{mg} / \mathrm{kg}$, risperidone $0.5 \mathrm{mg} / \mathrm{kg}$, or haloperidol $0.3 \mathrm{mg} / \mathrm{kg})$. Trilostane $(30 \mathrm{mg} / \mathrm{kg}$, i.p. $)$, a $3 \beta$ hydroxysteroid dehydrogenase $(3 \beta$-HSD) inhibitor, was injected 2 -h before i.p. injection of vehicle or antipsychotics. This dose of trilostane has been reported to significantly decrease the conversion of pregnenolone to progesterone (Potts et al, 1978, Korneyev et al, 1993). Indomethacin $(5 \mathrm{mg} / \mathrm{kg}$, i.p.), a $3 \alpha$-hydroxysteroid oxidoreductase ( $3 \alpha$-HSOR) enzyme inhibitor, was injected 20 min prior to antipsychotics or vehicle. This dose has been shown to inhibit the conversion of $5 \alpha$-dihydroprogesterone $(5 \alpha-$ $\mathrm{DHP}$ ) to ALLO in rats (Beyer et al, 1999). At $30 \mathrm{~min}$ after antipsychotic or vehicle administration, each rat was subjected to 10 trial sessions to record escape or avoidance behaviors as described above.

Similarly for assessment of climbing behavior, different groups of mice were treated with indomethacin, trilostane, or vehicle in the doses and at time interval identical to that used in above CAR experiment. These agents were used either alone or in combination with effective doses of antipsychotics (olanzapine $1 \mathrm{mg} / \mathrm{kg}$, risperidone $0.3 \mathrm{mg} / \mathrm{kg}$, haloperidol $0.2 \mathrm{mg} / \mathrm{kg}$ ) or vehicle. At $30 \mathrm{~min}$ after anti- psychotic treatment, all mice received apomorphine $(1 \mathrm{mg} / \mathrm{kg}$, s.c.) and $10 \mathrm{~min}$ later, the climbing behavior was scored at 5 -min interval for a period of $20 \mathrm{~min}$.

Experiment 5. We studied the influence of reduced GABAergic tone on antipsychotic-like effect of olanzapine, risperidone, and haloperidol using separate groups of animals. Rats were injected i.p. $\mathrm{GABA}_{\mathrm{A}}$ receptor antagonist bicuculline $(1 \mathrm{mg} / \mathrm{kg})$, or the negative modulator of $\mathrm{GABA}_{\mathrm{A}}$ receptor DHEAS $(1 \mathrm{mg} / \mathrm{kg}), 30 \mathrm{~min}$ prior to vehicle or antipsychotics (olanzapine $2 \mathrm{mg} / \mathrm{kg}$, risperidone $0.5 \mathrm{mg} / \mathrm{kg}$, or haloperidol $0.3 \mathrm{mg} / \mathrm{kg}$ ). At $30 \mathrm{~min}$ after vehicle or antipsychotic injection, each rat was subjected to 10 trial session of escape and avoidance behavior as described above.

Similarly for climbing test, different groups of mice were treated with bicuculline, DHEAS, or vehicle in the doses and at time interval same as that used in the above CAR experiment. These agents were used either alone or in combination with effective doses of antipsychotics, olanzapine $(1 \mathrm{mg} / \mathrm{kg})$, risperidone $(0.3 \mathrm{mg} / \mathrm{kg})$, haloperidol $(0.2 \mathrm{mg} / \mathrm{kg})$, or vehicle. At $30 \mathrm{~min}$ after vehicle or antipsychotic treatment, all mice received apomorphine (1 mg/ $\mathrm{kg}$, s.c.) and $10 \mathrm{~min}$ later, the climbing behavior was scored at 5 -min interval for a period of $20 \mathrm{~min}$. Vehicle-treated groups were also maintained simultaneously.

\section{Experiment 6: Influence of Social Isolation on Action of Antipsychotics}

We evaluated the actions of different antipsychotics in protracted social isolation paradigm, reported to downregulate $\mathrm{GABA}_{\mathrm{A}}$ receptor and to selectively decrease cerebral cortical content of ALLO without altering pregnenolone and progesterone concentration (Matsumoto et al, 1999; Guidotti et al, 2001). Mice were housed either in groups of five per cage $(24 \times 17 \times 12 \mathrm{~cm})$ or socially isolated. For social isolation, each mouse was kept individually (isolated in cage of $24 \times 17 \times 12 \mathrm{~cm}$ ) for 6 weeks before conducting the experiments. Animals were kept under standard 12:12-h light/dark cycle (lights on $0700 \mathrm{~h})$ in a temperature-controlled $\left(24 \pm 1^{\circ} \mathrm{C}\right)$ environment with ad libitum access to rodent chow (Lipton, India) and tap water.

Climbing test. Different cohorts of mice, both from group housed and isolates, were challenged with different doses of apomorphine $(0.25-1 \mathrm{mg} / \mathrm{kg}$, s.c.) or vehicle for climbing assessment. In a separate design, isolates or social mice were injected i.p. olanzapine (1-5 mg/kg), risperidone $(0.3 \mathrm{mg} / \mathrm{kg})$, haloperidol $(0.2 \mathrm{mg} / \mathrm{kg})$, or vehicle and $30 \mathrm{~min}$ thereafter challenged with apomorphine $(1 \mathrm{mg} / \mathrm{kg}$, s.c.) and following $10 \mathrm{~min}$ the climbing behavior was scored at 5 -min interval for a period of $20 \mathrm{~min}$ as described above.

Righting reflex test. We examined whether reported downregulation of $\mathrm{GABA}_{\mathrm{A}}$ receptor alter the actions of different antipsychotics in social isolates by measuring the duration of muscimol-induced loss of righting reflex. Group-housed or isolated mice were injected i.p. olanzapine $(0.05$ or $0.1 \mathrm{mg} / \mathrm{kg})$, risperidone $(0.1-0.3 \mathrm{mg} / \mathrm{kg})$, haloperidol $(0.05-0.1 \mathrm{mg} / \mathrm{kg})$, or vehicle $30 \mathrm{~min}$ before muscimol 
$(1.5 \mathrm{mg} / \mathrm{kg})$ and duration of loss of righting reflex was measured. Loss of righting reflex was defined as the inability of mouse to right itself within $30 \mathrm{~s}$ and the return of righting response as the ability of a mouse to right itself twice in $1 \mathrm{~min}$.

\section{Statistical Analysis}

The results of CAR were analyzed by one-way analysis of variance (ANOVA) followed by Dunnett's test. Climbing index data was analyzed using Kruskal-Wallis ANOVA followed by Mann-Whitney $U$ test. Comparison between two groups was performed by unpaired two-tailed $t$-tests. For multiple comparisons, two-way ANOVA followed by Bonferoni test was utilized. A value of $p<0.05$ was considered to be statistically significant in all cases.

\section{RESULTS}

\section{Experiment 1}

CAR inhibition by antipsychotics in rats. As shown in Figure 1a, olanzapine (one-way ANOVA: $p<0.0001$; $\mathrm{F}=187.4 ; \mathrm{df}=3,24 ; n=7$ ), risperidone (one-way ANOVA: $p<0.0001 ; \mathrm{F}=183.2 ; \mathrm{df}=3,24 ; n=7)$ and haloperidol (one-way ANOVA: $p<0.0001 ; \mathrm{F}=223.8 ; \mathrm{df}=3,24 ; n=7$ ) produced dose-related suppression of CAR behavior. A dose of $1.5 \mathrm{mg} / \mathrm{kg}$ of olanzapine produced approximately $40 \%$ block ( $p<0.001$ ) of avoidance responding, whereas $2 \mathrm{mg} / \mathrm{kg}$ almost completely $(90 \%)$ abolished $(p<0.001)$ the CAR. Administration of risperidone and haloperidol also produced around $80-90 \%$ inhibition of CAR at $0.5 \mathrm{mg} / \mathrm{kg}$ $(p<0.001)$ and $0.3 \mathrm{mg} / \mathrm{kg}(p<0.001)$, respectively. At doses lower than $1 \mathrm{mg} / \mathrm{kg}$ of olanzapine, $0.3 \mathrm{mg} / \mathrm{kg}$ risperidone, and $0.1 \mathrm{mg} / \mathrm{kg}$ haloperidol, no significant effect $(p>0.05)$ was observed. The doses of antipsychotics used here had no significant effect on escape performance.

Climbing behavior inhibition by antipsychotics in mice. Olanzapine $(1-2 \mathrm{mg} / \mathrm{kg}$, i.p.), risperidone $(0.3-0.4 \mathrm{mg} / \mathrm{kg}$, i.p.), and haloperidol $(0.2-0.3 \mathrm{mg} / \mathrm{kg}$, i.p.) exhibit dosedependent antagonism $(p=0.0006)$ to apomorphineinduced climbing behavior in mice (Figure 1b) with higher doses producing greater inhibition of climbing behavior. No apparent inhibition of climbing behavior was observed at doses lower than $0.5 \mathrm{mg} / \mathrm{kg}$ olanzapine, $0.2 \mathrm{mg} / \mathrm{kg}$ risperidone, or $0.1 \mathrm{mg} / \mathrm{kg}$ haloperidol.

\section{Experiments 2 and 3: Influence of ALLO or Its Endogenous Increase on The Action of Antipsychotics}

Experiment 2. As shown in Figure 2, the i.c.v. administration of ALLO was associated with dose-dependent inhibition of CAR behavior (one-way ANOVA: $p<0.0001$; $\mathrm{F}=219.1 ; \mathrm{df}=3,24 ; n=7$ ), while it did not affect escape response. Post hoc comparison revealed that at a dose of 2$4 \mu \mathrm{g} / \mathrm{rat}$, ALLO not only significantly $(p<0.001)$ suppressed (60-90\%, respectively) the CAR (Figure $2 \mathrm{a}$ ) but also the apomorphine-induced climbing behavior in mouse $(p=0.002)$ (Figure $2 \mathrm{~b})$. Lower doses were ineffective in blocking both behaviors. Furthermore, FGIN 1-27 $(1 \mu \mathrm{g} / \mathrm{rat}$ or mouse, i.c.v.) and progesterone $(20-30 \mathrm{mg} / \mathrm{kg}$, i.p.)
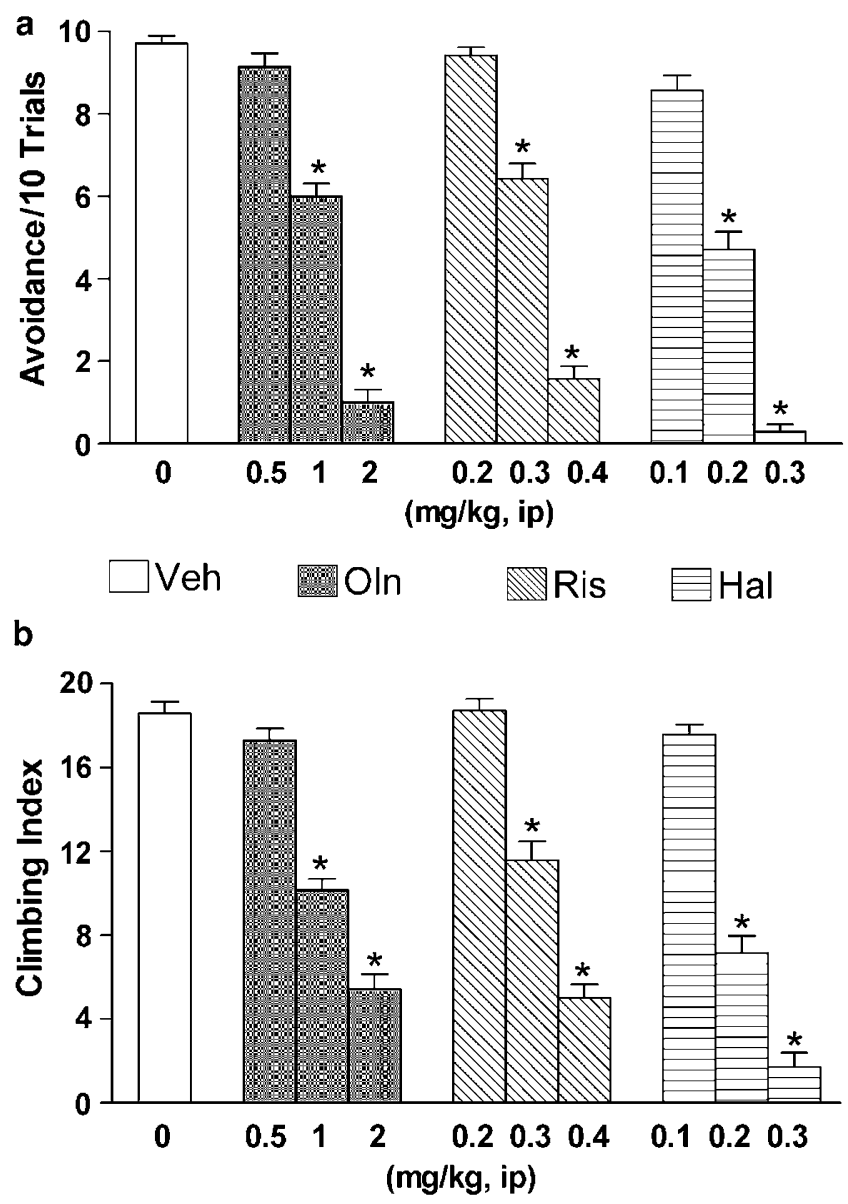

Figure I The effects of vehicle (Veh), olanzapine (Oln), risperidone (Ris), and Haloperidol (Hal) on (a) conditioned avoidance response (CAR) behavior in rats and (b) apomorphine-induced climbing behavior in mice. Animals were injected i.p. Oln, Ris, Hal, or Veh and 30 min thereafter, rats were assessed for CAR while mice were injected apomorphine $(\mathrm{I} \mathrm{mg} / \mathrm{kg}$, s.c.). For CAR inhibition, each trained rat was subjected to 10 trial sessions consisting of 20-s intertrial interval. For climbing behavior in mice, the total climbing scores was assessed at 5-min intervals for 20 min, starting 10 min after apomorphine administration. An index of 20 is the maximum possible for each mouse. Each column represents mean \pm SEM for a group of $(n=7)$ and significant at $* p<0.00$ I vs respective control.

effectively (60-90\% respectively) blocked the CAR $(p<0.0001)$ without significantly affecting the escape behavior. These doses also significantly $(p=0.002)$ antagonized the apomorphine-induced climbing in mice. However, lower doses failed to affect these behaviors.

Experiment 3. As shown in Figure 3, the i.c.v. injection of subeffective dose of ALLO $(1 \mu \mathrm{g} / \mathrm{rat})$ that exert minimal or no effect potentiated the effect of low dose of olanzapine $(1 \mathrm{mg} / \mathrm{kg}$, i.p.) on CAR inhibition (two-tailed $t$-test: $p<0.0001 ; t=15.81 ; \mathrm{df}=12 ; n=7)$. Results showed that the effect of subeffective dose of olanzapine $(1 \mathrm{mg} / \mathrm{kg})$ significantly inhibited (nearly 90\%) CAR in presence of ALLO $(1 \mu \mathrm{g} / \mathrm{rat})(p<0.001)$, as compared to the vehicle treatment (Figure 3a). The above drug treatment regimen in the rats had no effect on escape performance. Similarly, ALLO $(1 \mu \mathrm{g} /$ mouse, i.c.v.) potentiated the suppression of climbing behavior caused by olanzapine $(0.5 \mathrm{mg} / \mathrm{kg}$ ) (twotailed $t$-test: $p=0.0001 ; t=5.628 ; \mathrm{df}=12 ; n=7)$. On the 


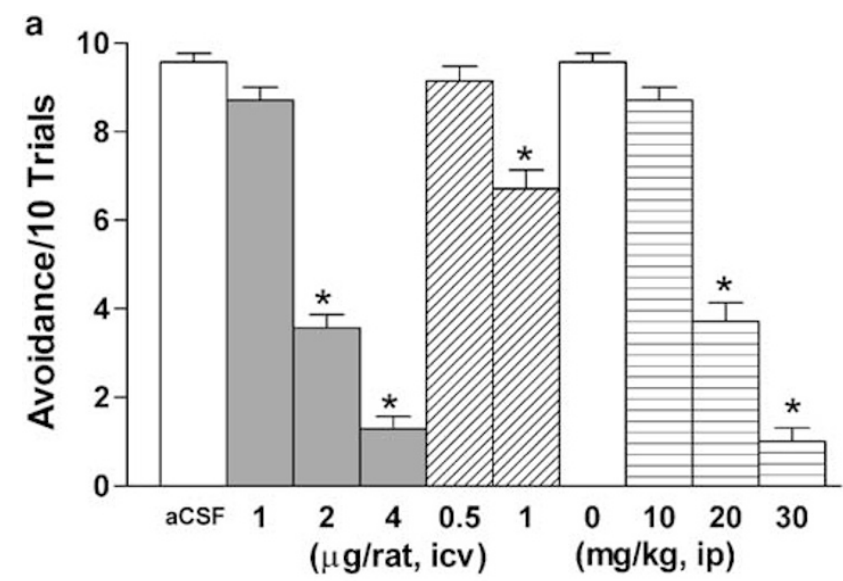

$\square$ Veh $\square$ ALLO UAFGIN $\boxminus$ Prog

b

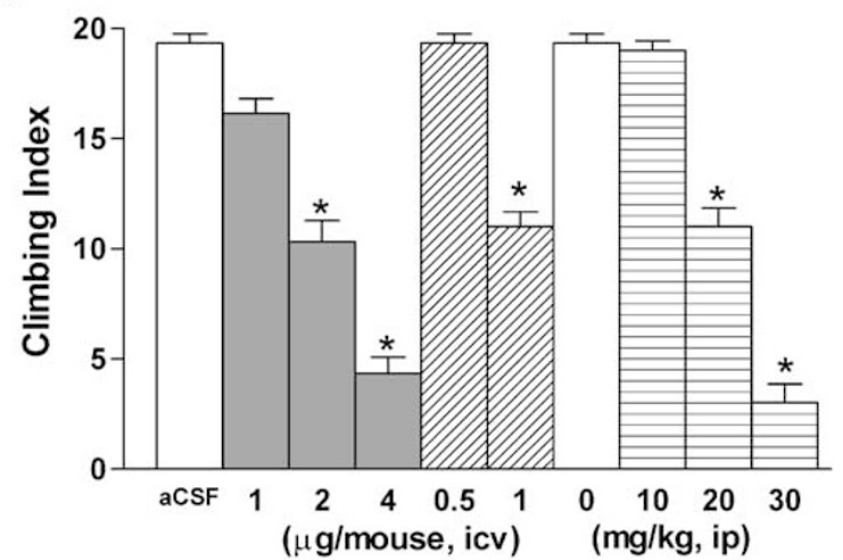

Figure 2 The effects of various doses of allopregnanolone (ALLO), FGIN I-27, progesterone (Prog), or vehicle on (a) CAR in rats and (b) apomorphine-induced climbing behavior in mice. At 30 min after i.p. injection of Prog or vehicle and 15 min after i.c.v. injection of ALLO, FGINI27, or aCSF, rats were subjected to CAR behavior while mice received apomorphine (I mg/ $/ \mathrm{kg}$, s.c.) climbing. For CAR inhibition, each trained rat was subjected to 10 trial session consisting of 20-s intertrial interval. For climbing behavior in mice, the total climbing scores was assessed at 5-min intervals for $20 \mathrm{~min}$, starting $10 \mathrm{~min}$ after apomorphine administration. An index of 20 is the maximum possible for each mouse. Each column represents mean \pm SEM for a group of ( $n=7$ rats or 6 mice) and significant at ${ }^{*} p<0.05$ vs respective control.

other hand, ALLO ( $1 \mu \mathrm{g} /$ mouse, i.c.v. $)$ did not significantly influence the effect of risperidone and haloperidol on CAR and climbing behavior (Figure 3a,b).

Administration of subeffective doses of FGIN 1-27 $(0.5 \mu \mathrm{g} /$ rat, i.c.v.) (two-tailed $t$-test: $p<0.0001 ; t=16.53 ; \mathrm{df}=12$; $n=7)$ or progesterone $(10 \mathrm{mg} / \mathrm{kg}$, i.p.) (two-tailed $t$-test: $p<0.0001 ; t=16.28 ; \mathrm{df}=12 ; n=7)$ significantly potentiated (80 or $70 \%$, respectively) the olanzapine $(1 \mathrm{mg} / \mathrm{kg}$, i.p.) induced suppression of CAR (Figure 3a,b) without affecting the escape performance. Similarly, antagonistic effect of olanzapine on apomorphine-induced climbing was potentiated by FGIN 1-27 (0.5 $\mu \mathrm{g} /$ mouse, i.c.v.) (two-tailed $t$-test: $p<0.0001 ; t=10.84 ; \mathrm{df}=12 ; n=7)$ and progesterone $(10 \mathrm{mg} / \mathrm{kg}$, i.p.) (two-tailed $t$-test: $p<0.0001 ; t=7.13$; $\mathrm{df}=12 ; n=7)$. These agents however failed to significantly

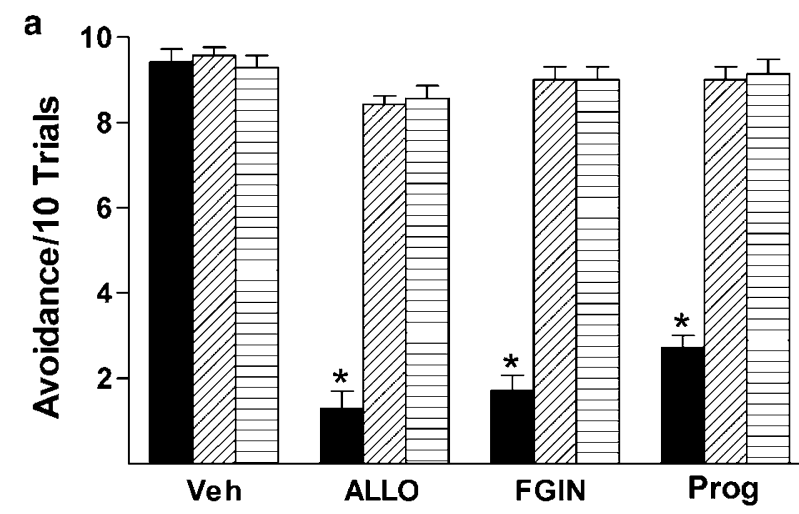

Clanzapine

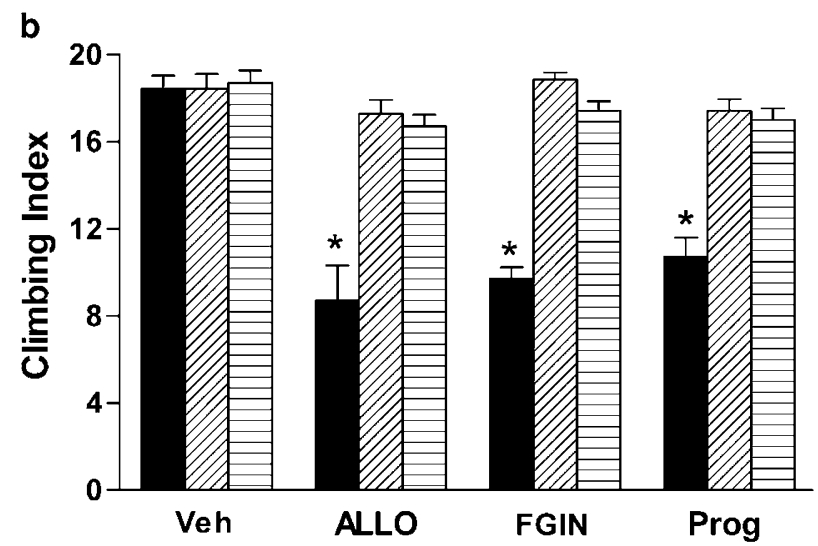

Figure 3 Effects of allopregnanolone (ALLO) or neurosteroidogenic agents on antipsychotic-induced antagonism of (a) CAR in rats and (b) apomorphine-induced climbing behavior in mice. Animals were injected i.c.v. ALLO (I $\mu \mathrm{g} /$ mouse), FGIN I-27 ( $0.5 \mu \mathrm{g} /$ mouse), aCSF, or i.p. progesterone (Prog) $(10 \mathrm{mg} / \mathrm{kg})$ or vehicle. At 15 or $30 \mathrm{~min}$ after i.c.v. or i.p. injection, respectively, animals injected i.p. vehicle or antipsychotics. The subeffective doses of antipsychotics used were olanzapine $1 \mathrm{mg} / \mathrm{kg}$, risperidone $0.3 \mathrm{mg} / \mathrm{kg}$, or haloperidol $0.1 \mathrm{mg} / \mathrm{kg}$ in rats and olanzapine $0.5 \mathrm{mg} / \mathrm{kg}$, risperidone $0.2 \mathrm{mg} / \mathrm{kg}$, or haloperidol $0.1 \mathrm{mg} / \mathrm{kg}$ in mice. At 30 min thereafter, trained rats were subjected to CAR while mice were injected with apomorphine (I mg/kg, s.c.). For CAR inhibition, each trained rat was subjected to 10 trial session consisting 20 -s intertrial interval. For climbing behavior in mice, the total climbing scores was assessed at 5-min intervals for $20 \mathrm{~min}$, starting 10 min after apomorphine administration. An index of 20 is the maximum possible for each mouse. Each column represents mean \pm SEM for a group of ( $n=7$ rats or 7 mice) and significant at ${ }^{*} p<0.001$ vs respective control.

alter the effects of risperidone and haloperidol in both the behaviors (Figure 3b).

\section{Experiments 4 and 5: Influence of Neurosteroid} Biosynthesis Inhibitors or Agents Capable of Reducing $\mathrm{GABA}_{\mathrm{A}}$ Receptor Activation on Behavioral Actions of Antipsychotics

Experiment 4. As depicted in Figure 4, inhibitory effect of olanzapine $(2 \mathrm{mg} / \mathrm{kg}$, i.p.) on CAR was significantly blocked $(p<0.001)$ by the neurosteroid synthesis blockers indomethacin $(5 \mathrm{mg} / \mathrm{kg}$, i.p.) (two-tailed $t$-test: $p<0.0001$; $t=18.00 ; \mathrm{df}=12 ; n=7)$ or trilostane $(30 \mathrm{mg} / \mathrm{kg}$, i.p.) (twotailed $t$-test: $p<0.0001 ; t=20.95 ; \mathrm{df}=12 ; n=7$ ) (Figure 4a). Similarly, the inhibition of apomorphine-induced climbing 

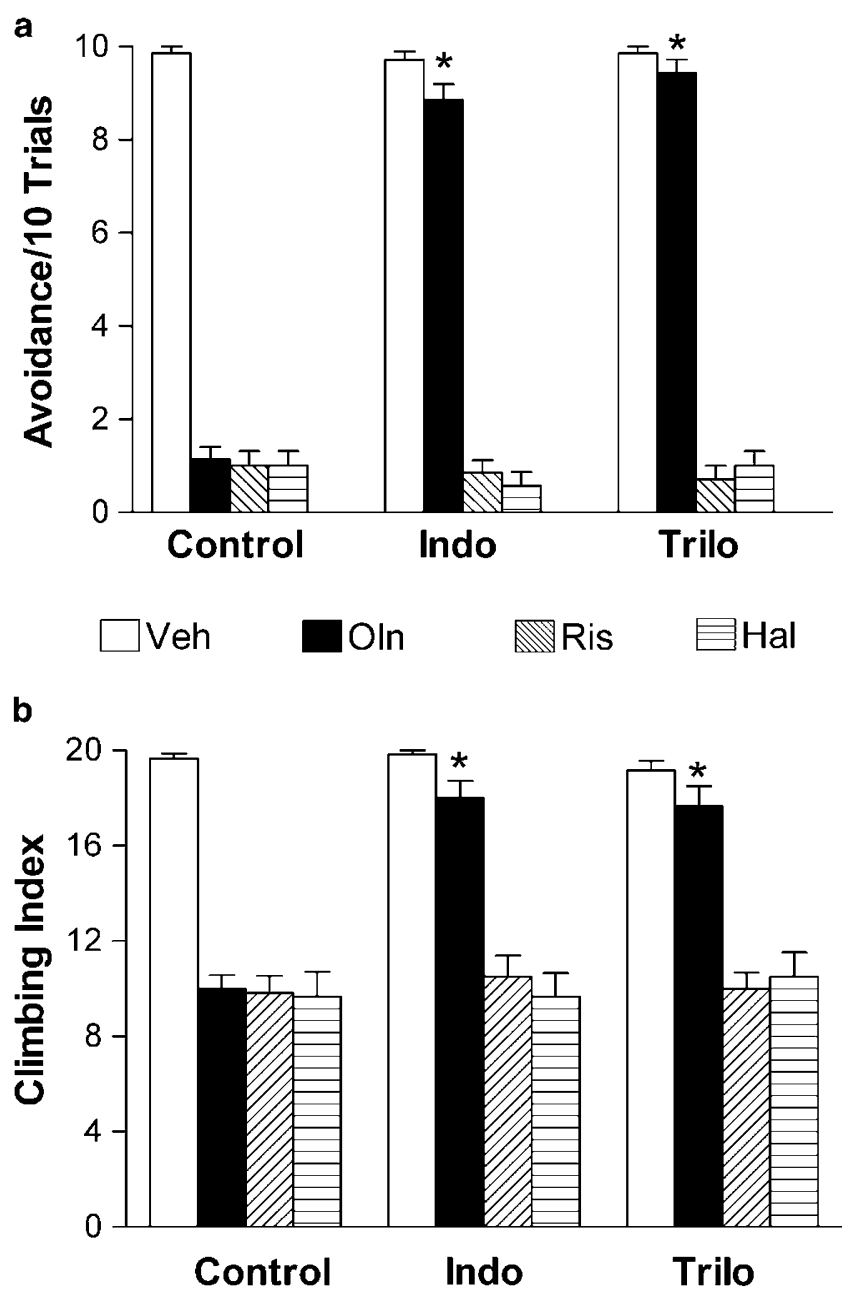

Figure 4 Influence of neuroactive steroid biosynthesis blockers on antipsychotic-induced inhibition of (a) CAR in rats and (b) antagonism of apomorphine-induced climbing behavior in mice. Animals were treated i.p. with Indomethacin $(5 \mathrm{mg} / \mathrm{kg})$ or trilostane $(30 \mathrm{mg} / \mathrm{kg}) 30$ or $120 \mathrm{~min}$, respectively, before olanzapine $(\mathrm{Oln})$, risperidone (Ris), haloperidol $(\mathrm{Hal})$, or vehicle. At $30 \mathrm{~min}$ thereafter, rats were subjected to CAR behavior while mice were injected apomorphine (I mg/ $/ \mathrm{kg}$, s.c.). For CAR behavior, each trained rat was subjected to 10 trial session consisting 20-s intertrial interval. For climbing behavior in mice, the total climbing scores was assessed at 5-min intervals for $20 \mathrm{~min}$, starting $10 \mathrm{~min}$ after apomorphine administration. An index of 20 is the maximum possible for each mouse. Each column represents mean \pm SEM for a group of ( $n=7$ rats or 6 mice) and significant at ${ }^{*} p<0.00$ I vs vehicle + olanzapine-treated group.

produced by olanzapine $(1 \mathrm{mg} / \mathrm{kg}$, i.p.) was significantly reversed by indomethacin (two-tailed $t$-test: $p<0.0001$; $t=8.593 ; \mathrm{df}=10 ; n=6)$ and trilostane (two-tailed $t$-test: $p<0.0001 ; t=7.502 ; \mathrm{df}=10 ; n=6$ ) (Figure $4 \mathrm{~b}$ ). However, the effects of risperidone and haloperidol on CAR and climbing behavior remained unaffected $(p>0.05)$. The neurosteroid inhibitors in the doses used here per se neither significantly affected avoidance responding and escape performance nor the climbing behavior.

Experiment 5. As shown in Figure 5, DHEAS ( $1 \mathrm{mg} / \mathrm{kg}$, i.p.), the most potent negative modulator of $\mathrm{GABA}_{\mathrm{A}}$ receptors (two-tailed $t$-test: $p<0.0001 ; t=22.01 ; \mathrm{df}=10 ; n=6$ ), reversed the inhibitory effects of olanzapine on CAR and climbing behavior (two-tailed $t$-test: $p<0.0001 ; t=9.010$;
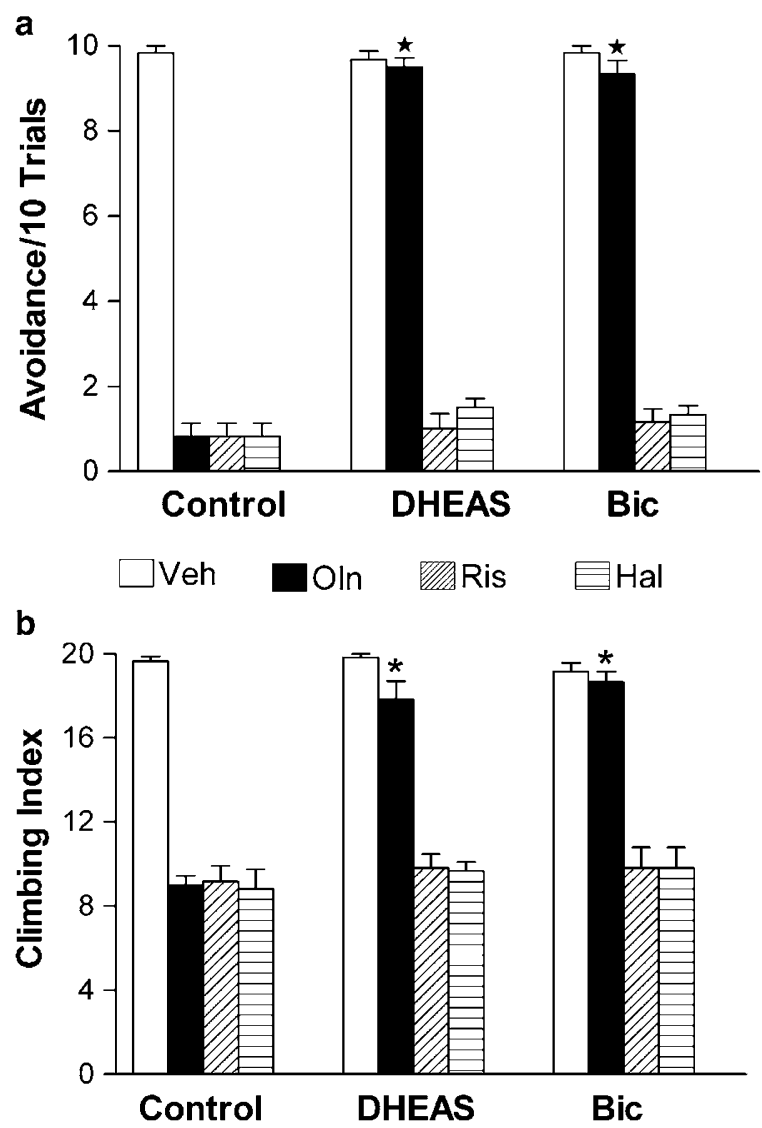

Figure 5 Effect of $G A B A_{A}$ receptor antagonist bicuculline (Bic) and $G_{A B A_{A}}$ negative neuroactive steroid modulator dehydroepiandrosterone sulphate (DHEAS) on antipsychotic induced (a) CAR inhibition in rats and (b) blockade of apomorphine-climbing behavior in mice. Animals were injected i.p. bicuculline (Bic) (I mg/kg), DHEAS (I mg/kg), or vehicle $30 \mathrm{~min}$ prior to i.p. injection of olanzapine (Oln), risperidone (Ris), haloperidol $(\mathrm{Hal})$, or vehicle. At $30 \mathrm{~min}$ thereafter, rats were subjected to CAR behavior while mice were injected apomorphine (I mg/ $/ \mathrm{kg}$, s.c.). For CAR behavior, each trained rat was subjected to 10 trial session consisting 20-s intertrial interval. For climbing behavior in mice, the total climbing scores was assessed at 5-min intervals for $20 \mathrm{~min}$, starting $10 \mathrm{~min}$ after apomorphine administration. An index of 20 is the maximum possible for each mouse. Each column represents mean \pm SEM for a group of $(n=6$ rats or 6 mice) and significant at $* p<0.0001$ vs vehicle + olanzapinetreated group.

$\mathrm{df}=10 ; n=6)$. On the other hand, the effects of risperidone or haloperidol (Figure 5a,b) remained unchanged. Bicuculline $\left(1 \mathrm{mg} / \mathrm{kg}\right.$, i.p.), the specific $\mathrm{GABA}_{\mathrm{A}}$ antagonist, reversed the effect of olanzapine on CAR (two-tailed $t$-test: $p<0.0001 ; t=18.75 ; \mathrm{df}=10 ; n=6)$ and climbing behavior (two-tailed $t$-test: $p<0.0001 ; t=10.77 ; \mathrm{df}=10 ; n=6$ ) without altering the effects of risperidone and haloperidol. Further, Bicuculline or DHEAS treatment in the doses used here per se did not significantly alter the avoidance responding/escape performance in rats or climbing behavior in mice.

\section{Experiment 6: Influence of Social Isolation on the Effects of Antipsychotics}

As shown in Figure 6a, socially isolated subjects showed enhanced sensitivity $(p<0.001)$ in climbing test, as the 
a

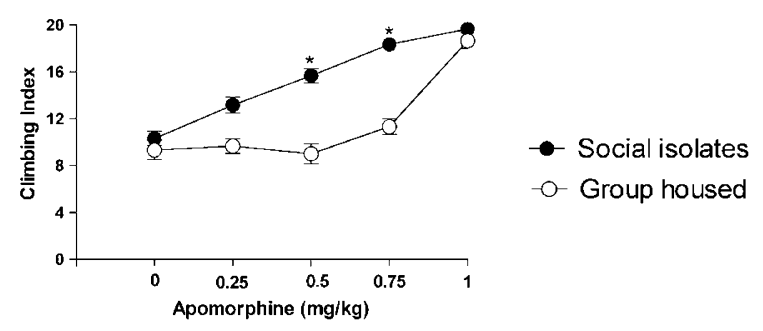

b
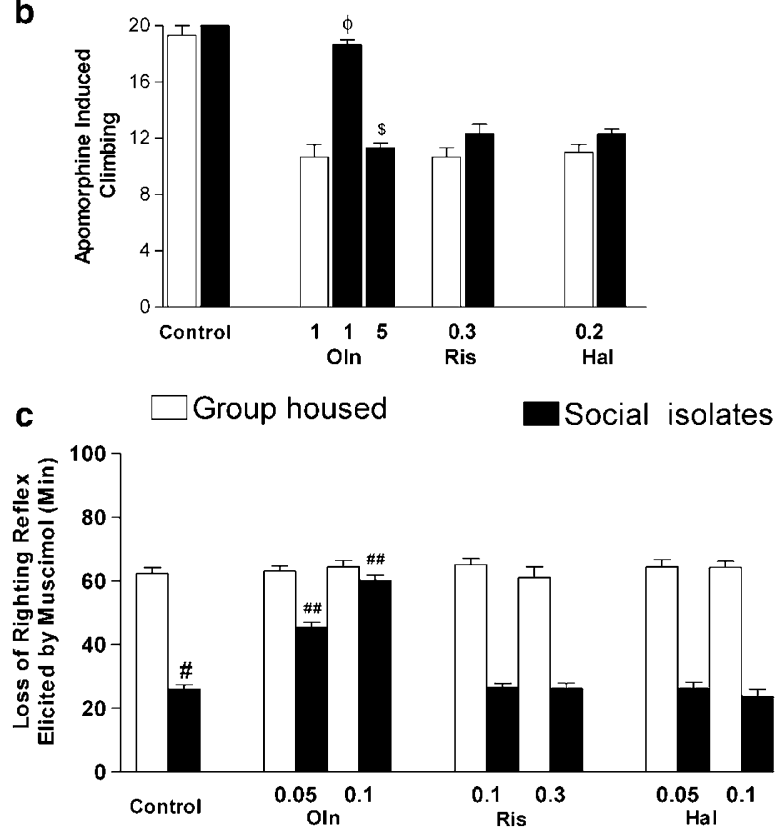

Figure 6 Effects of social isolation on mouse behaviors. (a) Apomorphine-induced climbing, (b) its antagonism by antipsychotic and (c) muscimol-induced loss of righting reflex and its modification by antipsychotics. Animals were housed in groups $(n=6$ per cage) or individually (socially isolated) for 6 weeks before the start of the experiments. (a) Apomorphine $(0.25-1 \mathrm{mg} / \mathrm{kg}$ ) or vehicle was injected s.c. and (b) olanzapine (Oln), risperidone (Ris), or haloperidol (Hal) was injected $30 \mathrm{~min}$ before apomorphine (I mg/kg, s.c.). The total climbing scores was assessed at 5 -min intervals for $20 \mathrm{~min}$, starting $10 \mathrm{~min}$ after apomorphine administration. An index of 20 is the maximum possible for each mouse. (c) Oln, Ris, Hal, or Veh was administered 30 min prior to muscimol ( $1.5 \mathrm{mg} / \mathrm{kg}$, i.p.) and duration of loss of righting reflex was measured. Each data represents mean \pm SEM for a group of ( $n=12$ mice) and significant at ${ }^{*} p<0.01$ vs the respective control value, ${ }^{\Phi} p<0.05$ vs Oln $(\mathrm{mg} / \mathrm{kg})$ in group-housed animals, ${ }^{\$} p<0.05$ vs socially isolated Oln ( $\mathrm{mg} / \mathrm{kg}$ )-treated social isolates, ${ }^{\#} p<0.00 \mid$ vs vehicle-treated grouphoused control, ${ }^{\# \#} p<0.001$ vs vehicle-treated socially isolated mice.

lowest dose of apomorphine $(0.75 \mathrm{mg} / \mathrm{kg})$ produced $100 \%$ climbing score in isolates when compared to group-housed mice $(1 \mathrm{mg} / \mathrm{kg})$. Interestingly, a $4-5$ times higher dose of olanzapine (two-tailed $t$-test: $p<0.0001 ; t=11.01 ; \mathrm{df}=21$; $n=12$ ) was required to antagonize apomorphine-induced $(1 \mathrm{mg} / \mathrm{kg}$, s.c.) climbing in social isolates as compared to group-housed subjects. On the other hand, no significant difference was observed in doses required to block apomorphine climbing by risperidone $(0.3 \mathrm{mg} / \mathrm{kg}$, i.p.) or haloperidol $(0.2 \mathrm{mg} / \mathrm{kg}$, ip) in either group-housed or socially isolated subjects.

Further, the duration of loss of righting reflex induced by muscimol $(1.5 \mathrm{mg} / \mathrm{kg}$, i.p. $)$ was shortened in socially isolated mice $(p<0.001)$ compared to group-housed animals.
Olanzapine $(0.05-0.1 \mathrm{mg} / \mathrm{kg}$, i.p.) dose dependently normalized this decreased loss of righting reflex $(p<0.001)$ in socially isolated mice, while risperidone and haloperidol had no such effect (Figure 6b).

The duration of loss of righting reflex induced by muscimol $(1.5 \mathrm{mg} / \mathrm{kg}$, i.p. $)$ was shortened $(p<0.0001)$ in social isolates as compared to group-housed mice. Olanzapine $(0.05-0.1 \mathrm{mg} / \mathrm{kg}$, i.p.) dose dependently normalized this decreased loss of righting reflex (ANOVA: $p<0.0001$; $\mathrm{F}=78.46 ; \mathrm{df}=2.66 ; n=12)$ in socially isolated mice, while risperidone and haloperidol had no such effect (Figure 6c).

\section{DISCUSSION}

Our data demonstrate that the neuroactive steroid ALLO, positive modulator of $\mathrm{GABA}_{\mathrm{A}}$ receptor, plays vital role in antipsychotic-like action of olanzapine but not of risperidone or haloperidol in rodents. The study employed young, healthy males to avoid gender and age-related variations of neurosteroids (Orentreich et al, 1984; Finn and Gee, 1993; Robel et al, 1995; Genazzani et al, 1998; Schumacher et al, 2003) that might affect the behavioral parameters per se. The present results replicate previous findings that olanzapine, risperidone, and haloperidol dose specifically inhibit avoidance response without affecting the escape behavior in rats (Moore et al, 1992; Wadenberg et al, 2001) and antagonized apomorphine-induced climbing (Costall et al, 1978; Strange, 2001). Similarly, exogenous injection (i.c.v.) of the neurosteroid ALLO and neurosteroidogenic agents like the MDR agonist FGIN 1-27 or i.p. injection of the neurosteroid precursor progesterone (Bitran et al, 2000; Paul and Purdy, 1992; Romeo et al, 1992; Rupprecht et al, 1993; Prasad et al, 1994; Lambert et al, 1995) also dose specifically antagonized these behaviors. Indeed, we and others (Khisti et al, 2002; Rupprecht et al, 1999) have recently demonstrated the neuroleptic-like properties of the neurosteroid ALLO and its precursor progesterone. Multiple studies indicated that the changes in the physiological rhythm of progesterone secretion, together with the normal metabolism of this steroid to ALLO, might contribute towards the genesis of several mental disorders. For example, postmenopausal women exhibit increased vulnerability to the onset of schizophrenic episodes (Hafner et al, 1993); whereas, during premenstrual phase, symptoms such as anxiety and discomfort are expressed (Guidotti and Costa, 1998; Bailey and Cohen, 1999). Severe psychotic symptoms and dysphoria occurring postpartum have been attributed to the withdrawal of progesterone secretions (Brockington and Meakin, 1994; Harris et al, 1994).

Next, we investigated whether the enhanced or reduced brain neuroactive steroids modulate the neuroleptic properties of olanzapine compared to that of haloperidol and risperidone. Interestingly, it was found that the central (i.c.v.) administration of ALLO or MDR agonist FGIN 1-27 and i.p. injection of progesterone, a peripheral precursor in their subeffective doses, augmented the effects of olanzapine on CAR and climbing behaviors. By contrast, these pretreatments failed to significantly affect the actions of risperidone and haloperidol in above behavioral paradigms. Further, necessity of ALLO in mode of action of different antipsychotics was studied using specific de novo neurosteroid 
biosynthesis inhibitors. Trilostane and indomethacin, at the doses used in the study, per se did not significantly affect the avoidance/escape behavior or apomorphine-induced climbing. This insignificant effect on base line activity in these behaviors could be attributed to the fact that endogenous levels of ALLO in naïve male rats are below relevant physiological concentrations (Purdy et al, 1991). However, pretreatment with trilostane and indomethacin abolished the actions of olanzapine but not of risperidone and haloperidol, thereby implying the vital role of neuroactive steroids in the action of olanzapine. It may be recalled that while trilostane inhibits the enzyme $3 \beta$ hydroxysteroid oxidoreductase ( $3 \beta$-HSOR) (Potts et al, 1978 , Korneyev et al, 1993) that catalyses the conversion of pregnanolone to progesterone, indomethacin inhibits the cytosolic isoform of enzyme $3 \alpha$-HSOR (Beyer et al, 1999) that reduces the conversion of $5 \alpha$-DHP to ALLO. Our results indicate that metabolism of progesterone to neurosteroids like ALLO is essential for antipsychotic-like effect of olanzapine. This strongly supports the assumption that progesterone-derived neuroactive steroids contribute to the actions of olanzapine but not of risperidone and haloperidol (Barbaccia et al, 2001; Marx et al, 2000, 2003). The recent reports support our observation that levels of GABAergic neuroactive steroid are significantly lower in schizophrenics (Kurumaji et al, 1997, 2000). Moreover, numerous evidences suggest that variations in the steady-state level of neuroactive steroids, especially ALLO in brain, may be relevant to pathophysiology of a range of psychiatric disorders (Guidotti et al, 2000, 2001). However, it is important to note that our results do not exclude the involvement of other GABAergic neuroactive steroids like THDOC since olanzapine (Marx et al, 2000) and clozapine (Barbaccia et al, 2001) modify levels of different brain neuroactive steroids including THDOC.

A large body of evidence indicates an inhibitory influence of $\mathrm{GABA}_{\mathrm{A}}$ receptors on the nigrostriatal (Bartholini, 1980) and the mesolimbic (Pacitti et al, 1982) dopaminergic systems. Olanzapine is known to block dopamine receptors with relatively weaker potency and the blockade of receptors, other than $D_{2}$, is thought to be responsible for its atypical antipsychotic profile (Bymaster et al, 1999). Moreover, ALLO represents the most potent positive modulator of $\mathrm{GABA}_{\mathrm{A}}$ receptor and is known to diminish basal and stress-induced dopaminergic transmission in the brain by its action on $\mathrm{GABA}_{\mathrm{A}}$ receptors (Motzo et al, 1996). Our observation that bicuculline pretreatment antagonized the effects of olanzapine on CAR- and apomorphineinduced climbing behaviors suggests that the antipsychoticlike action of olanzapine could be mediated via activation of $\mathrm{GABA}_{\mathrm{A}}$ receptors. Consequently it may be speculated that the influence of ALLO on dopaminergic neurotransmission might be mediated via $\mathrm{GABA}_{\mathrm{A}}$ receptors (Motzo et al, 1996; Khisti et al, 2002) perhaps through modulation of intracellular signaling mechanisms like protein kinase $\mathrm{C}$ (PKC) (Brunig et al, 1999; Brussard et al, 2000; Liu et al, 2000). That the activation or inhibition of PKC increases or decreases, respectively, dopamine release in striatum has already been demonstrated (Gimbalvo, 1988). Interestingly, interaction of ALLO with $\mathrm{GABA}_{\mathrm{A}}$ receptors prevents the PKC from phosphorylating $\mathrm{GABA}_{\mathrm{A}}$ receptor itself and prolongs the receptor ion channel open time (Twyman and Macdonald, 1992; Brussard et al, 2000). Further, PKC deficiency results in enhanced $\mathrm{GABA}_{\mathrm{A}}$ receptor sensitivity to allosteric modulators including ALLO or pregnanolone (Baulieu et al, 2001; Hodge et al, 2002). One line of evidence maintains that $\mathrm{GABA}_{\mathrm{A}}$ receptors participate in controlling the activity of dopaminergic neurons (Santiago and Westerink, 1992) and exerts tonic inhibition of dopamine release in rat striatum (Gruen et al, 1992; Smolders et al, 1995). It is noteworthy that olanzapine does not exercise a direct action on the $\mathrm{GABA}_{\mathrm{A}}$ receptors (Bymaster et al, 1996; Schotte et al, 1996) but alters the density of $\mathrm{GABA}_{\mathrm{A}}$ receptors in hippocampus and temporal cortex (FarnbachPralong et al, 1998). It is further stated that olanzapine or clozapine would assist substantially in reversing an under active GABAergic system in schizophrenia (Farnbach-Pralong et al, 1998). Thus, it seems reasonable to assume that olanzapine-induced elevations in ALLO increase the GABAergic tone or modulates the PKC function that may inhibit the hyperdopaminergic tone, leading to neuroleptic manifestation. However, ALLO does not display direct affinity towards $\mathrm{D}_{2}$ receptors (Wadenberg et al, 2001), but influences the dopamine-mediated behaviors in rodents (Khisti et al, 2002). The possibility of ALLO and olanzapine interaction with dopaminergic neurotransmission, in light of the indirect GABAergic modulation is unclear at this stage and needs further investigations.

In order to better understand the neurosteroid olanzapine interaction and involvement of GABAergic transmission in the antipsychotic-like effect of olanzapine, we studied the effect of DHEAS, the $\mathrm{GABA}_{\mathrm{A}}$ receptor allosteric antagonist. Our results indicate that prior administration of DHEAS reversed the olanzapine-induced behavior in CAR and apomorphine climbing. This approach confirms and extends our hypothesis that modulation of $\mathrm{GABA}_{\mathrm{A}}$ receptors is the underlying mechanism in antipsychotic-like action of olanzapine but not of haloperidol and risperidone. Earlier reports have demonstrated an increase in DHEAS level, a putative stimulator of dopamine release (Murray and Gillies, 1997), also in schizophrenia (Oades and Schepker, 1994). Recently, it has been reported that treatment with the atypical antipsychotic clozapine, but not haloperidol, decreases the levels of DHEAS in rat cortex (Nechmad et al, 2003), thereby increasing GABAergic tone and leading to improvement of psychotic symptoms (Purdon et al, 2001). Indeed, monitoring of the DHEA/ DHEAS levels following olanzapine treatment may help to determine their relevance in antipsychotic mode of action.

Physiological and pharmacologically induced fluctuations in brain concentrations of neuroactive steroids, such as those encountered during pregnancy and pseudopregnancy result in selective modulation of function and expression of $\mathrm{GABA}_{\mathrm{A}}$ receptors in cerebral cortex and hippocampus (Uzunova et al, 2003). A protracted social isolation paradigm was used to further investigate the role of $\mathrm{GABA}_{\mathrm{A}}$ receptors and of the neurosteroid ALLO in the actions of different antipsychotics. Social isolation of rodents for 6 weeks is known to downregulate the $\mathrm{GABA}_{\mathrm{A}}$ receptor and to selectively decrease ALLO levels without altering other neurosteroids in brain (Serra et al, 2000; Dong et al, 2001; Guidotti et al, 2001).

Isolation of animals engenders enhanced sensitivity of apomorphine-induced climbing response. The basis for 
enhanced climbing susceptibility in socially isolated mice is unclear at this stage. However, this could possibly be attributed to increased dopamine levels in the brain secondary to the depletion of cortical ALLO (Dazzi et al, 2002) and decreased $\mathrm{GABA}_{\mathrm{A}}$ receptor functioning (Serra et $a l, 2000)$ in socially isolated animals. Further, different antipsychotics used in the study antagonized the apomorphine-induced climbing in both socially isolated and grouphoused subjects. However, nearly five times the dose of olanzapine was required to inhibit the climbing response in social isolates as compared to that required in the grouphoused animals. These results are interesting in light of the reports that risperidone and haloperidol have been shown to possess a high dopamine $D_{1} / D_{2}$ receptor blockade while olanzapine affinity for these receptors is relatively weak (Bymaster et al, 1996; Kapur et al, 1998, 1999; Tauscher et al, 1999). Another possibility is that olanzapine may exert its effect through other receptor mechanisms in a manner similar to ALLO. We suggest that the difference in efficacy in restoring the antagonism of apomorphine-induced climbing behavior by olanzapine and other antipsychotics in social isolates should be further investigated. Prolonged social isolation has been shown to affect the functional coupling between the recognition site for GABA and those for allosteric modulators such as muscimol, benzodiazepines (Dong et al, 2001). Thus, similar to previous studies (Guidotti et al, 2001), we observed that the duration of loss of righting reflex elicited by the $\mathrm{GABA}_{\mathrm{A}}$ receptor agonist muscimol was markedly shortened in socially isolated mice. Interestingly olanzapine, but not risperidone and haloperidol, normalized the duration of muscimol-induced decrease of righting reflex in socially isolated mice. Recently, the selective serotonin reuptake inhibitor (SSRI) fluoxetine has been shown not only to normalize the levels of brain ALLO content but also pentobarbital and muscimolinduced decrease of righting reflex in socially isolated mice (Matsumoto et al, 1999). Thus, it can be postulated that olanzapine normalized the endogenous cortical stores of ALLO that is reduced in socially isolated mice and thereby upregulated the $\mathrm{GABA}_{\mathrm{A}}$ receptors to normalize muscimolelicited loss of righting reflex.

In conclusion, these results support the hypothesis that the antipsychotic-like effect of olanzapine is due to enhanced GABAergic tone or $\mathrm{GABA}_{\mathrm{A}}$ receptor function as a likely consequence of augmented brain content of neuroactive steroids especially ALLO (Majewska et al, 1986; Morrow et al, 1987, 1990). Furthermore, a recent report suggests that olanzapine increases midbrain allopregnanolone levels when infused in ventral tegmental area, and the behavioral effect of olanzapine is mediated through increase in ALLO, independent of progesterone or corticosterone (Frye and Seliga, 2003). Thus, these preclinical results provide the specific behavioral evidence that the neurosteroid ALLO contributes to the neuroleptic-like effect of olanzapine that may be clinically relevant. It is moreover possible that ALLO may play a role in mediating other therapeutic actions of olanzapine and its consequent reducing of symptoms. In addition to ALLO, olanzapine may also affect other neurosteroids and this possibility will require further investigations. Thus, the involvement of ALLO represents an important physiological modulator that contributes to the sensitivity of $\mathrm{GABA}_{\mathrm{A}}$ receptors to $\mathrm{GABA}$
(Guidotti et al, 2001). In turn, the latter will affect dopaminergic transmission (Khisti et al, 2002) and may play a key role in the control of psychiatric behavior by olanzapine. These findings further indicate that development of drugs targeted at neuroactive steroid mechanisms might provide a new direction in therapeutic intervention for psychiatric disorders.

\section{ACKNOWLEDGEMENTS}

This study was supported by the senior research fellowship grant from Council of Scientific and Industrial Research, New Delhi to KH (CSIR \# 9/128(68)/2K2/EMR-I) and emeritus grant of All India Council of Technical Education, New Delhi to CTC (AICTE \# 1-51/FD/EF (10)/2002-2003/I). We gratefully acknowledge the support from Regione Autonoma della Sardegna L.R 11/04/1996 n.19 and thank Dr Anne Farmer and Dr NK Subhedar for editorial assistance.

\section{REFERENCES}

Akbarian S, Kim JJ, Potkin SG, Hagman JO, Tafazzoli A, Bunney WE (1995). Gene expression for glutamic acid decarboxylase is reduced without loss of neurons in prefrontal cortex of schizophrenics. Arch Gen Psychiatry 52: 258-266.

Akwa Y, Ladurelle N, Covey DF, Baulieu E (2001). The synthetic enantiomer of pregnenolone sulfate is very active on memory in rats and mice, even more so than its physiological neurosteroid counterpart: distinct mechanisms? Proc Natl Acad Sci USA 98: 14033-14037.

Arnt J (1982). Pharmacological specificity of conditioned avoidance response inhibition in rats: inhibition by neuroleptics and correlation to dopamine receptor blockade. Acta Pharmacol Toxicol 51: 321-329.

Bailey JW, Cohen LS (1999). Prevalence of mood and anxiety disorders in women who seek treatment for premenstrual syndrome. J Womens Health Gend Based Med 8: 1181-1184.

Barbaccia ML, Affricano D, Purdy RH, Maciocco E, Spiga F, Biggio G (2001). Clozapine, but not haloperidol, increases brain concentrations of neuroactive steroids in the rat. Neuropsychopharmacology 25: 489-497.

Bartholini G (1980). Interaction of striatal dopaminergic, cholinergic and GABAergic neurons: relation to extrapyramidal function. Trends Pharmacol Sci 1: 138-140.

Baulieu EE, Robel P, Schumacher M (2001). Neurosteroids: beginning of the story. Int Rev Neurobiol 46: 1-32.

Beasley Jr CM, Tollefson G, Tran P, Satterlee W, Sanger T, Hamilton S (1996). Olanzapine versus placebo and haloperidol: acute phase results of the North American double-blind olanzapine trial. Neuropsychopharmacology 14: 111-123.

Benes FM (1995). Altered glutamatergic and GABAergic mechanisms in the cingulate cortex of the schizophrenic brain. Arch Gen Psychiatry 52: 1015-1024.

Benes FM, Berretta S (2001). GABAergic interneurons: implications for understanding schizophrenia and bipolar disorder. Neuropsychopharmacology 25: 1-27.

Beyer C, Gonzalez-Flores O, Ramirez-Orduna JM, GonzalezMariscal G (1999). Indomethacin inhibits lordosis induced by ring a-reduced progestins: possible role of $3 \alpha$-oxoreduction in progestin-facilitated lordosis. Horm Behav 35: 1-8.

Bilsky EJ, Inturrisi CE, Sadee W, Hruby VJ, Porreca F (1996). Competitive and non-competitive NMDA antagonists block the development of antinociceptive tolerance to morphine, but not 
to selective mu or delta opioid agonists in mice. Pain 68: 229-237.

Bitran D, Foley M, Audette D, Leslie N, Frye CA (2000). Activation of peripheral mitochondrial benzodiazepine receptors in the hippocampus stimulates allopregnanolone synthesis and produces anxiolytic-like effects in the rat. Psychopharmacology 151: 64-71.

Bixo M, Andersson A, Winblad B, Purdy RH, Backstrom T (1997). Progesterone, 5alpha-pregnane-3, 20-dione and 3alpha-hydroxy5alpha-pregnane-20-one in specific regions of the human female brain in different endocrine states. Brain Res 764: 173-178.

Brockington IF, Meakin CJ (1994). Clinical clues to the etiology of puerperal psychosis. Prog Neuropsychopharmacol Biol Psychiatry 18: 417-429.

Brunig I, Sommer M, Hatt H, Bormann J (1999). Dopamine receptor subtypes modulate olfactory bulb gamma-aminobutyric acid type A receptors. Proc Natl Acad Sci USA 96: 2456-2460.

Brussard AB, Wossink J, Lodder JC, Kits KS (2000). Progesterone metabolite prevents protein kinase $\mathrm{C}$ dependent modulation of gamma-aminobutyric acid type A receptors in oxytocin neurons. Proc Natl Acad Sci USA 97: 3625-3630.

Bymaster F, Falcone JF, Bauzon D, Kennedy JS, Schenck K, DeLapp NW et al (2001). Potent antagonism of $5-\mathrm{HT}_{3}$ and $5-\mathrm{HT}_{6}$ receptors by olanzapine. Eur J Pharmacol 430: 341-349.

Bymaster FP, Calligaro DO, Falcone JF, Marsh RD, Moore NA, Tye NC (1996). Radioreceptor binding profile of the atypical antipsychotic olanzapine. Neuropsychopharmacol 14: 87-96.

Bymaster FP, Falcon JF (2000). Decreased binding affinity of olanzapine and clozapine for human muscarinic receptor subtypes in intact clonal $\mathrm{CHO}$ cells in physiological medium. Eur J Pharmacol 390: 245-248.

Bymaster FP, Moore NA, Nakazawa T (1999). Review of the preclinical pharmacology of olanzapine; a marker of new class of antipsychotic. Jpn J Clin Psychopharmacol 2: 885-911.

Cameron DL, Williams JT (1993). Dopamine D1 receptors facilitate transmitter release. Nature 366: 344-347.

Carpenter WT, Buchanan RW, Kirkpatrick B, Breier AF (1999). Diazepam treatment of early signs of exacerbation in schizophrenia. Am J Psychiatry 156: 299-303.

Costall B, Naylor RJ, Nohria V (1978). Climbing behavior induced by apomorphine in mice: a potential model for the detection of neuroleptic activity. Eur J Pharmacol 1: 39-50.

Dazzi L, Serra M, Vacca G, Ladu S, Latrofa A, Trapani G et al (2002). Depletion of cortical allopregnanolone potentiates stress-induced increase in cortical dopamine output. Brain Res 5: $135-139$.

Dong E, Matsumoto V, Uzunova I, Sugaya H, Takahata H, Nomura $\mathrm{H}$ et al (2001). Brain $5 \alpha$-dihydroprogesterone and allopregnanolone synthesis in a mouse model of protracted social isolation. Proct Natl Acad Sci USA 98: 21849-21854.

Drew KL, O’Connor WT, Kehr J, Ungerstedt U (1990). Regional specific effects of clozapine and haloperidol on GABA and dopamine release in rat basal ganglia. Eur J Pharmacol 23: 385-397.

Farnbach-Pralong D, Bradbury R, Copolov D, Dean B (1998). Clozapine and olanzapine treatment decreases rat cortical and limbic $\mathrm{GABA}_{\mathrm{A}}$ receptors. Eur J Pharmacol 349: R7-R8.

Finn DA, Gee KW (1993). The influence of estrus cycle on neurosteroid potency at the gamma-aminobutyric acid A receptor complex. J Pharm Exp Ther 265: 1374-1379.

Frye CA (1995). The neurosteroid $3 \alpha, 5 \alpha$-THP has antiseizure and possible neuroprotective effects in an animal model of epilepsy. Brain Res 696: 113-120.

Frye CA, Seliga A (2003). Effects of olanzapine infusions to the ventral tegmental area on lordosis and midbrain $3 \alpha, 5 \alpha$-THP concentrations in rats. Psychopharmacol 170: 132-139.

Genazzani AR, Petraglia F, Bernardi F, Casarosa E, Salvestroni C, Tonetti A et al (1998). Circulating levels of allopregnanolone in humans: gender, age and endocrine influences. J Clin Endocrinol Metab 83: 2099-2103.

George MS, Guidotti A, Rubinow D, Pan B, Mikalauskas K, Post RM (1994). CSF neuroactive steroids in affective disorders: pregnenolone, progesterone, and DBI. Biol Psychiatry 35: 775-780.

Gimbalvo CT (1988). Protein kinase C and dopamine release-II. Effect of dopamine acting drugs in vivo. Biochem Pharmacol 37: 4009-4017.

Gruen RJ, Friedhoff AJ, Coale A, Moghaddam B (1992). Tonic inhibition of striatal dopamine transmission: effects of benzodiazepine and $\mathrm{GABA}_{\mathrm{A}}$ receptor antagonists on extracelllular dopamine levels. Brain Res 599: 51-56.

Guidotti A, Costa E (1998). Can the antidysphoric and anxiolytic profiles of selective serotonin reuptake inhibitors be related to their ability to increase brain $3 \alpha, 5 \alpha$-tetrahydroprogesterone (allopregnanolone) availability? Biol Psychiatry 44: 865-873.

Guidotti A, Dong E, Matsumoto K, Pinna G, Rasmusson AM, Costa E (2001). The socially isolated mouse: a model to study the putative role of allopregnanolone and 5alpha-dihydroprogesterone in psychiatric disorders. Brain Res Rev 37: 110-115.

Guidotti A, Pesold C, Costa E (2000). New neurochemical markers for psychosis: a working hypothesis of their operation. Neurochem Res 25: 1207-1218.

Hafner H, Riecher-Rossler A, an der Heiden W, Maurer K, Fatkenheuer B, Lottler W (1993). Generating and testing a casual explanation of gender difference in age at first onset of schizophrenia. Psychol Med 23: 925-940.

Harris B, Lovelt L, Newcombe RG, Read GF, Walker R, RiadFahmy D (1994). Maternity blues and major endocrine changes: Cardiff puerperal mood and hormone study II. BMJ 308: 949-953.

Hill M, Parizek A, Bicikova M, Havlikova H, Klak J, Fait T et al (2000). Neuroactive steroids, their precursors, and polar conjugates during parturition and postpartum in maternal and umbilical blood: 1. Identification and simultaneous determination of pregnanolone isomers. J Steroid Biochem Mol Biol 75: 237-244.

Hirani K, Khisti RT, Chopde CT (2002). Behavioral actions of ethanol in Porsolt's forced swim test: modulation by 3alpha-hydroxy-5alpha-pregnan-20-one. Neuropharmacology 43: $1339-1350$.

Hodge CW, Raber J, McMahon T, Walter H, Sanchez-Perez AM, Olive MF et al (2002). Decreased anxiety-like behavior, reduced stress hormones, and neurosteroid supersensitivity in mice lacking protein kinase C epsilon. J Clin Invest 110: 1003-1010.

Kapur S, Zipursky RB, Remington G (1999). Clinical and theoretical implications of $5-\mathrm{HT}_{2}$ and $\mathrm{D}_{2}$ receptor occupancy of clozapine, risperidone and olanzapine in schizophrenia. $\mathrm{Am} \mathrm{J}$ Psychiatry 156: 286-293.

Kapur S, Zipursky RB, Remington G, Jones C, DaSilva J, Wilson AA et al (1998). $5 \mathrm{HT}_{2}$ and $\mathrm{D}_{2}$ receptor occupancy of olanzapine receptor in schizophrenia: a PET investigation. Am J Psychiatry 155: 921-928.

Khisti RT, Chopde CT (2000). Serotonergic agents modulate antidepressant-like effect of the neurosteroid $3 \alpha$-hydroxy- $5 \alpha$ pregnan-20-one in mice. Brain Res 865: 291-300.

Khisti RT, Chopde CT, Abraham E (2000). GABAergic involvement in motor effects of an adenosine $\mathrm{A}_{2 \mathrm{~A}}$ receptor agonist in mice. Neurosci Lett 251: 85-88.

Khisti RT, Deshpande LS, Chopde CT (2002). The neurosteroid $3 \alpha-$ hydroxy- $5 \alpha$-pregnan-20-one affects dopamine-mediated behavior in rodents. Psychopharmacol 161: 120-128.

Khisti RT, Mandhane SN, Chopde CT (1998). The neurosteroid $3 \alpha-$ hydroxy- $5 \alpha$-pregnan-20-one induces catalepsy in mice. Neurosci Lett 251: 85-88.

Korneyev AY, Costa E, Guidotti A (1993). During anestheticinduced activation of hypothalamic pituitary adrenal axis, blood 
borne steroid fail to contribute to the anesthetic effect. Neuroendocrinology 57: 559-565.

Kurumaji A, Nomoto H, Yoshikawa T, Okubo Y, Toru M (2000). An association study between two missense variations of the benzodiazepine receptor (peripheral) gene and schizophrenia in a Japanese sample. J Neural Transm 107: 491-500.

Kurumaji A, Wakai T, Toru M (1997). Decreases in peripipheraltype benzodiazepine receptors in postmortem brains of schizophrenics. J Neural Transm Gen Sect 104: 1361-1370.

Lambert JJ, Belelli D, Hill-Venning C, Peters JA (1995). Neurosteroids and $\mathrm{GABA}_{\mathrm{A}}$ receptor function. Trends Pharmacol Sci 16: 295-303.

Law-Tho D, Hirsch JC, Crepel F (1994). Dopamine modulation of synaptic transmission in rat prefrontal cortex: an in vitro electrophysiological study. Neurosci Res 21: 151-160.

Lewis DA (2000). GABAergic local circuit neurons and prefrontal cortical dysfunction in schizophrenia. Brain Res Rev 31: 270-276.

Liu F, Wan Q, Pristupa ZB, Yu XM, Wang YT, Niznik HB (2000). Direct protein-protein coupling enables cross-talk between dopamine $\mathrm{D}_{5}$ and gamma-aminobutyric acid A receptors. Nature 403: $274-280$.

Madhusoodanan S, Brenner R, Cohen CL (1999). Role of atypical antipsychotics in the treatment of psychosis and agitation associated with dementia. CNS Drugs 12: 135-150.

Madhusoodanan S, Sinha S, Brenner R, Gupta S, Bogunovic O (2001). Use of olanzapine for elderly patients with psychotic disorders: a review. Ann Clin Psychiatry 13: 201-213.

Majewska MD, Harrison NL, Schwartz RD, Barker JL, Paul SM (1986). Steroid hormone metabolites are barbiturate-like modulators of the $\mathrm{GABA}_{\mathrm{A}}$ receptor. Science 232: 1004-1007.

Marx CE, Duncan GE, Gilmore JH, Lieberman JA, Morrow AL (2000). Olanzapine increases allopregnanolone in the rat cerebral cortex. Biol Psychiatry 47: 1000-1004.

Marx CE, VanDoren MJ, Duncan GE, Lieberman JA, Morrow AL (2003). Olanzapine and Clozapine increase the GABAergic Neuroactive steroid allopregnanolone in rodents. Neuropsychopharmacology 28: 1-13.

Matsumoto K, Uzunova V, Pinna G, Taki K, Uzunova DP, Watanabe $\mathrm{H}$ et al (1999). Permissive role of brain allopregnanolone content in the regulation of pentobarbital induced righting reflex loss. Neuropharmacology 38: 955-963.

Moore NA, Axton MS (1988). Production of climbing behavior in mice requires both $\mathrm{D}_{1}$ and $\mathrm{D}_{2}$ receptor activation. Psychopharmacology 91: 263-266.

Moore NA, Rees G, Sanger G, Tye NC (1994). Effects of olanzapine and other antipsychotic agents on responding maintained by a conflict schedule. Behav Pharmacol 5: 196-202.

Moore NA, Tye NC, Axton MS, Risius FC (1992). The behavioral pharmacology of olanzapine, a novel 'atypical' antipsychotic agent. J Pharmacol Exp Ther 262: 545-551.

Morrow AL, Pace JR, Purdy RH, Paul SM (1990). Characterization of steroid interactions with gamma-aminobutyric acid receptorgated chloride ion channels: evidence for multiple steroid recognition sites. Mol Pharmacol 37: 263-270.

Morrow AL, Suzdak PD, Paul SM (1987). Steroid hormone metabolites potentiate GABA receptor-mediated chloride ion flux with nanomolar potency. Eur J Pharmacol 142: 483-485.

Motzo C, Porceddu ML, Maira G, Flore G, Concas A, Dazzi L (1996). Inhibition of basal and stress-induced dopamine release in the cerebral cortex and nucleus accumbens of freely moving rats by the neurosteroid allopregnanolone. J Psychopharmacol 10: 266-272.

Murray HE, Gillies GE (1997). Differential effects of neuroactive steroids on somatostatin and dopamine secretion from primary hypothalamic cell cultures. J Neuroendocrinol 9: 287-295.

Nechmad A, Mayan R, Ramadan E, Morad O, Poyurovsky M, Weizman A (2003). Clozapine decreases rat brain dehydro- epiandrosterone and dehydroepiandrosterone sulphate levels. Eur J Neuropsychopharmacol 13: 29-31.

Nowakowska E, Chodera A, Kus K (1999). Influence of olanzapine on cognitive functions and catalepsy in rats after single and chronic administration. Pol J Pharmacol 51: 295-300.

O'Connor WT (2001). Functional neuroanatomy of the ventral striopallidal GABA pathway: new sites of intervention in the treatment of schizophrenia. J Neurosci Methods 109: 31-39.

Oades RD, Schepker R (1994). Serum gonadal steroid hormones in young schizophrenic patients. Psychoneuroendocrinology 19: 373-385.

Orentreich N, Brind H, Rizer RL, Vogehman JH (1984). Age changes and sex difference in dehydroepiandrosterone sulphate concentrations throughout adulthood. J Clin Endocrinol Metab 59: 551-555.

Osborne PG, O'Connor WT, Beck O, Ungerstedt U (1994). Acute versus chronic haloperidol: relationship between tolerance to catalepsy and striatal and accumbens dopamine, GABA and acetylcholine release. Brain Res 14: 20-30.

Pacitti C, Fiadone G, Gasbari A, Civitelli D, Scarnati E (1982). Electrophysiological evidence for an inhibitory accumbens entopenducular pathway in the rat. Neurosci Lett 33: 35-50.

Paul SM, Purdy RH (1992). Neuroactive steroids. FASEB J 6: 2311-2322.

Paxinos G, Franklin RBJ (1997). The Mouse Brain in Stereotaxic Coordinates. Academic Press: San Diego.

Paxinos G, Watson C (1998). The Rat Brain in Stereotaxic Coordinates. Academic Press: San Diego.

Penit-Soria J, Audinat E, Crepel F (1987). Excitation of rat prefrontal cortical neurons by dopamine: an in vitro electrophysiological study. Brain Res 425: 263-274.

Pennartz CM, Dolleman-Vander Weel MJ, Kitai ST, Lopes Da Silva FH (1992). Presynaptic dopamine $D_{1}$ receptors attenuate excitatory and inhibitory inputs to the shell region of the rat nucleus accumbens studied in vitro. J Neurophysiol 67: 1325-1334.

Pirot S, Godbout R, Mantz J, Tassin JP, Glowinski J, Thierry AM (1992). Inhibitory effects of ventral tegmental area stimulation on the activity of prefrontal cortical neurons: evidence for the involvement of both dopaminergic and GABAergic components. Neuroscience 49: 857-865.

Potts GO, Creange JE, Harding HR, Schane HP (1978). Trilostane, an orally active inhibitor of steroid biosynthesis. Steroids 32: 257-267.

Pralong E, Jones RS (1993). Interactions of dopamine with glutamate and GABA-mediated synaptic transmission in the rat entorhinal cortex in vitro. Eur J Neurosci 5: 760-767.

Prasad VVK, Vegesna SR, Welch M, Lieberman S (1994). Precursors of neurosterids. Proct Natl Acad Sci USA 91: 3220-3223.

Purdon SE, Labelle A, Boulay L (2001). Neuropsychological change in schizophrenia after 6 weeks of Clozapine. Schizophr Res 48: 57-67.

Purdy RH, Moore Jr PH, Morrow AL, Paul SM (1992). Neurosteroids and $\mathrm{GABA}_{\mathrm{A}}$ receptor function. $A d v$ Biochem Psychopharmacol 47: 87-92.

Purdy RH, Morrow AL, Moore Jr PH, Paul SM (1991). Stressinduced elevations of gamma-aminobutyric acid type A receptor-active steroids in the rat brain. Proc Natl Acad Sci USA 15: 4553-4557.

Richelson E, Souder T (2000). Binding of antipsychotic drugs to human brain receptors. Focus on newer generation compounds. Life Sci 68: 29-39.

Robel P, Baulieu EE (1995). Neurosteroids: biosynthesis and function. Crit Rev Neurobiol 9: 383-394.

Robel P, Baulieu EE, Synguelakis M, Halberg E (1987). Chronobiologic dynamics of delta 5-3 beta-hydroxysteroids and 
glucocorticoids in rat brain and plasma and human plasma. Prog Clin Biol Res 227A: 451-465.

Robel P, Young J, Corpechot C, Mayo W, Perche F, Haug M et al (1995). Biosynthesis and assay of neurosteroids in rats and mice: functional correlates. J Steroid Biochem Mol Biol 53: 355-360.

Robertson GS, Fibiger HC (1996). Effects of olanzapine on regional C-Fos expression in rat forebrain. Neuropsychopharmacology 14: 105-110.

Romeo E, Auta J, Kozikowski AP, Ma D, Papadopoulos V, Puia G (1992). 2-Aryl-3-indoleacetamides (FGIN-1): a new class of potent and specific ligands for the mitochondrial DBI receptor (MDR). J Pharmacol Exp Ther 262: 971-978.

Roth BL, Craigo SC, Choudhary MS, Uluer A, Monsma FJ, Shen Y (1994). Binding of typical and atypical antipsychotic agents to 5-hydroxytryptamine-6 and 5-hydroxytryptamine-7 receptors. J Pharmacol Exp Ther 268: 1403-1410.

Rupprecht R, Holsboer F (1999). Neuroactive steroids: mechanisms of action and neuropsychopharmacological perspectives. Trends Neurosci 22: 410-416.

Rupprecht R, Koch M, Montkowski A, Lancel M, Faulhaber J, Harting J et al (1999). Assessment of neuroleptic-like properties of progesterone. Psychopharmacology 143: 29-38.

Rupprecht R, Reul LMMH, Trapp T, Steensel B, Wetzel C, Damm K et al (1993). Progesterone-receptor mediated effects of neuroactive steroids. Neuron 11: 523-530.

Sanchez-Blazquez P, Garcia-Espana A, Garzon J (1995). In vivo injection of antisense oligodeoxyneucleotides to $G$ alpha subunits and supraspinal analgesia evoked by $\mathrm{mu}$ and delta opioid agonists. J Pharmacol Expt Ther 275: 1590-1596.

Santiago M, Westerink BHC (1992). The role of GABA receptors in the control of nigrostriatal dopaminergic neurons: dualprobe microdialysis study in awake rats. Eur J Pharmacol 219: 175-181.

Schotte A, Janssen PF, Gommeren W, Luyten WH, Van Gompel P, Lesage AS et al (1996). Risperidone compared with new and reference antipsychotic drugs: in vitro and in vivo receptor binding. Psychopharmacology 124: 57-73.

Schumacher M, Weill-Engerer S, Liere P, Robert F, Franklin RJM, Garcia-Segura LM et al (2003). Steroid hormones and neurosteroids in normal and pathological aging of the nervous system. Prog Neurobiol 71: 3-29.
Serra M, Littera M, Pisu MG, Muggironi M, Purdy RH, Biggio G (2000). Steroidogenesis in rat brain induced by short- and longterm administration of carbamazepine. Neuropharmacology 39: 2448-2456.

Smolders I, de Klippel N, Sarre S, Ebinger G, Michotte Y (1995). Tonic GABAergic modulation of striatal dopamine release studied by in vivo microdialysis in the freely moving rat. Eur J Pharmacol 284: 83-91.

Strange PG (2001). Antipsychotic drugs: importance of dopamine receptors for mechanisms of therapeutic actions and side effects. Pharmacol Rev 53: 119-133.

Tauscher J, Kufferle B, Asenbaum S, Fischer P, Pezawas L, Barnas $C$ et al (1999). In vivo ${ }^{123}$ I IBZM SPECT imaging of striatal dopamine-2 receptor occupancy in schizophrenic patients treated with olanzapine in comparison to clozapine and haloperidol. Psychopharmacology 141: 175-181.

Twyman RE, Macdonald Rl (1992). Neurosteroid regulation of $\mathrm{GABA}_{\mathrm{A}}$ receptor single-channel kinetic properties of mouse spinal cord neurons in culture. J Physiol 456: 215-245.

Uzunova V, Melanie C, Kohler C, Uzunov DP, Wrynn AS (2003). Region-specific dysregulation of allopregnanolone brain content in the olfactory bulbectomized rat model of depression. Brain res 796: 1-8.

Van Kammen DP (1977). Gamma-aminobutyric acid (GABA) and the dopamine hypothesis of schizophrenia. Am J Psychiatry 134: 138-143.

Wadenberg MLG, Soliman A, Vanderspek S, Kapur S (2001). Dopamine $\mathrm{D}_{2}$ receptor occupancy is a common mechanism underlying animal models of antipsychotics and their clinical effects. Neuropharmacology 25: 633-641.

Wang M, Seippel L, Purdy RH, Backstorm T (1996). Relationship between symptom severity and steroid variation in women with premenstrual syndrome: study on serum pregnenolone, pregnenolone sulphate, $5 \alpha$-pregnane-3,20-dione and $3 \alpha$-hydroxy- $5 \alpha$ pregnan-20-one. J Clin Endocrinol Metab 81: 1076-1082.

Wieland S, Lan NC, Mirasedeghi S, Gee KW (1991). Anxiolytic activity of the progesterone metabolite $5 \alpha$-pregnan-3 $\alpha$-ol-20-one. Brain Res 565: 263-268.

Zimmerberg B, Blaskey LG (1998). Prenatal stress effects are partially ameliorated by prenatal administration the neurosteroid allopregnanolone. Pharmacol Biochem Behav 59: 819-827. 